Article

\title{
Development of the Hybrid Operation Method of a Multi-Geothermal Heat Pump System and Absorption Chiller-Heater
}

\author{
Young-Ju Jung ${ }^{1}$, Hyo-Jun Kim ${ }^{1}$, Kyung-Ju Shin ${ }^{1}$, Jae-Hun Jo ${ }^{2}$, Yong-Shik Kim ${ }^{3}$ and \\ Young-Hum Cho ${ }^{4, *}$
}

1 Department of Architectural Engineering, Graduate School of Yeungnam University, 280 Daehak-Ro, Gyeongsan, Gyeongbuk 38541, Korea; E-Mails: nun1228@naver.com (Y.-J.J.); kimyo@ynu.ac.kr (H.-J.K.); shinkeoungju@naver.com (K.-J.S.)

2 Department of Architectural Engineering, Inha University, 100 Inha-ro, Nam-gu, Incheon 22212, Korea; E-Mail: jhjo@inha.ac.kr

3 Division of Architecture and Urban Planning, Incheon national University, 119 Academy-ro, Yeonsu-gu, Incheon 22012, Korea; E-Mail: newkim@incheon.ac.kr

4 School of Architecture, Yeungnam University, 280 Daehak-Ro, Gyeongsan, Gyeongbuk 38541, Korea

* Author to whom correspondence should be addressed; E-Mail: yhcho@ynu.ac.kr; Tel.: +82-53-810-3081; Fax: +82-53-814-3675.

Academic Editor: Hossam A. Gabbar (Gaber)

Received: 8 June 2015 / Accepted: 6 August 2015 / Published: 31 August 2015

\begin{abstract}
Considerable efforts have been made to reduce the energy consumption of buildings due to the energy crisis, and, the Korean government has supported the use of renewable energy through various grants. Among the possible renewable energy sources, geothermal energy can be used regardless of the outside weather. Therefore, energy consumption can be reduced considerably in summer and winter. Despite the increasing use of renewable energy, the use of renewables has not been operating appropriately. Therefore, this study examined some of the problems of the operation of renewable energy and some possible improvements. The aim of the study is to evaluate a building containing an actual installed multi-geothermal heat pump (Multi-GHP) system, in terms of the energy efficiency. In addition, this study evaluated the present control system and the method of complex operation regarding existing heat sources systems and GHP systems through a simulation. The results can be regarded as the result of a hybrid operation method for the
\end{abstract}


improvement of an existing operation. Therefore, the Multi-GHP system energy use of a hybrid operation condition of the Multi-GHP systems and the absorption (ABS) chiller-heater system was reduced compared to the operation condition of the Multi-GHP system, and the total energy consumption of the heat source equipment was reduced. The proposed operation plan was evaluated after applying the system to a building. These results showed that the efficient operation of a Multi-GHP hybrid operation method is possible. As a result, the GHP energy use of Multi-GHP systems and the ABS chiller-heater system was reduced by $30 \%$ compared to existing operation and the total energy consumption of heat source equipment was reduced by $78 \%$.

Keywords: renewable energy; multi-geothermal heat pump (Multi-GHP) system; building energy; transient system simulation program (TRNSYS); hybrid operation; absorption (ABS) chiller-heater

\section{Introduction}

The energy crisis in the world economy is a major problem, as published by the International Energy Agency (IEA) in the 17 June 2014 mid-term outlook for the oil market report (Oil Medium-Term Market Report [1]). The world oil demand is expected to increase by an annual average of $1.3 \%$ by 2019. On the other hand, oil is a limited resource. Therefore, efforts to replace fossil fuels due to oil depletion are ongoing and necessary. In particular, Korea is the world's $10^{\text {th }}$ highest energy consumer but it imports more than $97 \%$ of its energy. The percentage of energy in the total amount of imports is increasing gradually. An energy crisis may endanger the economy. Consequently, national efforts are needed to respond to the future energy crisis. Therefore, the government is fostering a renewable energy industry as a means of handling the energy crisis. The development of renewable energy in a resource poor country is important. Among the renewable energy systems available, geothermal energy has been highlighted as highly efficient and safely operable without being effected by outdoor air. In addition, it is one of the oldest renewable energy resources in the world, and it supplies the most energy.

Studies on the trends of GHP systems and importance of GHP systems are as follows. In the past, many studies have focused on efficiency enhancement and performance evaluations of various GHP systems [2-5]. Accordingly, studies of GHP are in progress from many worldwide perspectives. Haehnlein et al. [6] published a comprehensive overview of the current international legal status for the use of shallow geothermal energy. In their study, an international survey was performed using a questionnaire sent to more than 60 countries worldwide. Luo et al. [7] and Rees and Curtis [8] examined the importance of the research trends and the design of a GHP system. Study on the performance of the GHP systems is as follows. In addition, Byun et al. [9] studied a fuel cell driven ground source heat pump (GSHP) system applied in a community building, and the heat pump system performance was analyzed using computational methods. Considering the long-term stability of the soil temperature and energy conservation of the system, Zhai et al. [10] suggested that a higher indoor temperature be set for the indoor environment. Bakirci et al. [11] examined the performance of a solar-GSHP system with vertical ground handling equipment (GHE). The results suggested that this solar-GSHP system can be 
used for heating applications in the cold climate regions of Turkey. Yang [12] assessed the performance characteristics of a vertical U-bend direct-expansion ground source (geothermal) heat pump system (DX GSHPS) for both heating and cooling. Their study highlighted the energy efficiency of the DX GSHP system. Kim et al. [13] reported that the design of a proper indoor temperature for variable outdoor conditions is very important for maintaining high system performance and reliability in a hybrid solar-geothermal $\mathrm{CO}_{2}$ heat pump system. Ozgener and Hepbaslib [14] examined the energetic and exergetic modeling of GSHP systems for system analysis and performance assessments. Salvalai [15] reported a parameter estimation study of a water-to-water heat pump model, implemented in IDA Indoor Climate and Energy (IDA-ICE) simulation environment, is presented and validated using experimental data. Some studies on economic evaluation of GHP systems are the following: Esen et al. [16] conducted performance experiments and economic analyses of a horizontal GSHP system. A detailed cost analysis was presented and the payback periods when substituting for different local fuel/power sources were determined. Studies on the energy efficiency of GHP systems include the following: Ally et al. [17,18] provided excellent data on the energy savings and the fraction of energy that could be extracted from the ground for both space heating and water heating. They described the advanced building envelope characteristics, instrumentation, data acquisition, tabulated data collected, analysis, measures of performance, and conclusions for ground-coupled heat pumps for reducing the energy footprint in buildings. Chen et al. [19] discussed an underground water-source water-loop heat-pump (UWSWLHP) air-conditioning system for tall apartment buildings in Beijing. Sivasakthivel et al. [20] provided extensive data from India highlighting the energy and $\mathrm{CO}_{2}$ saving potential of GSHP system. In the case of GSHP, the $\mathrm{CO}_{2}$ emissions are between 4022 million $\mathrm{kg}$ and 12,071 million $\mathrm{kg}$, resulting in a reduction of about $24.54 \%$ in a year. They estimated that India can save a minimum of $1639 \mathrm{GW}$ to $18,760 \mathrm{GW}$ of electricity and 1248 million tons to 14,280 million tons of $\mathrm{CO}_{2}$ emission annually by employing GSHP technology. Studies on the composite heat source utilizing GHP system are as follows: recognition of the economic and convenient effects of geothermal heating and cooling systems in Korea is increasing because renewable energy systems supply business and installation obligations in public buildings. Geothermal energy, however, is only in charge of a part of the building load due to the high initial installation cost. Moreover, its efficiency is reduced due to the use of independent existing heat sources. Accordingly, research into GHP systems is on-going, focusing on increasing the efficiency of underground heat exchangers and evaluating the performance.

Complex operations combining solar heat and GHP have been studied in Korea and abroad. When a complex heat source was used, Kong et al. [21] examined the operation priority based on the energy consumption. Hwang et al. [22], Ozgener and Hepbasli [23,24], Nam [25], and Shu et al. [26] examined solar heat and GHP systems and suggested an efficient way of operation through performance analysis. Ozgener and Hepbasli $[23,24]$ assessed the complex operations of existing heat sources systems and GHP systems and reported the optimal capacity selection in terms of energy consumption in the case of design. Jeon et al. [27] reported that the use of a GHP system energy-efficient should be a priority but this study of the method of complex operation was inadequate. Yu et al. [28] evaluated the practical suggestions of complex operations regarding existing heat sources systems and GHP systems. The present study was conducted based on their results. Opening and closing of the air handling unit (AHU) added to the control point and sequencing control of the time delay was proposed. 
On the other hand, operation was not considered when examining the performance of the GHP unit or to reflect the indoor thermal environment. In addition, the focus was adjusted to compare the energy. The debate on the performance improvement of the heat of room environment or equipment is insufficient. Kalz et al. [29] emphasized the substantial impact of auxiliary energy use on the efficiency of heating and cooling performance. Kalz et al. [30] also presented a comprehensive analysis of the heating and cooling concepts of 11 low-energy buildings in terms of energy use, efficiency and occupant thermal comfort. Therefore, with reference to the following study was carried out in this study. In addition, the research into complex operations regarding multi-geothermal heat pump (Multi-GHP) systems and absorption (ABS) chiller-heaters is insufficient. Therefore, a hybrid operation method was proposed for a Multi-GHP system and ABS chiller-heater. In this study, after selecting a building containing an actual installed GHP, the use of GHP systems was maximized in terms of the energy efficiency. This paper proposes and evaluates the methods of hybrid operation regarding ABS chiller-heater and GHP systems through simulations.

\section{Building and System Information}

\subsection{Building Information}

The chosen building is the K-University Hospital located in Chilgok, Gyeongbuk (Korea). Figure 1 shows the exterior of the building.

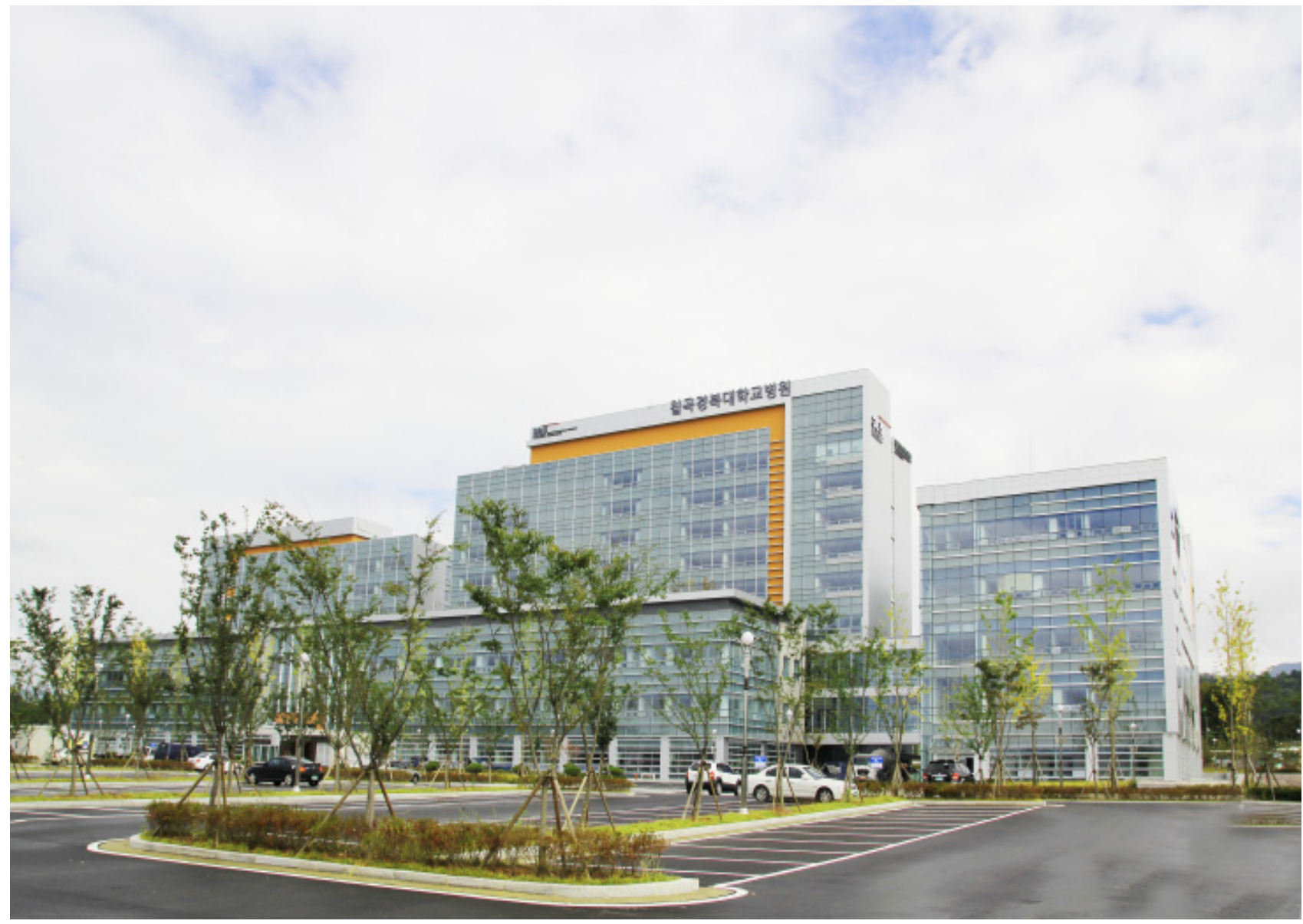

Figure 1. Exterior of the building. 
As shown in Table 1, the building has three stories below ground and nine above ground and an installed GHP unit with 530 tonne refrigerant (RT) capacity as the renewable energy source.

Table 1. Summary of the building information. GHP: geothermal heat pump.

\begin{tabular}{cc}
\hline Building name & Kyungpook University Hospital \\
\hline Building stories & Building with three stories below ground and nine above ground \\
Building area & $9737 \mathrm{~m}^{2}$ \\
Total floor area & $81,928 \mathrm{~m}^{2}$ \\
GHP system area of installation & $2263 \mathrm{~m}^{2}$ \\
Installed GHP systems capacity & $6.708 \mathrm{GJ} / \mathrm{h}(530$ Refrigeration ton $)$ \\
\hline
\end{tabular}

\subsection{System Information}

Table 2 lists the room conditions for the heat source system in the building with an installed GHP system (6.708 GJ/h (530 Refrigeration ton) and an ABS chiller $36.70 \mathrm{GJ} / \mathrm{h}$ (2900 refrigeration ton)). As shown in Figure 2, the heat source water produced in the heat source system was supplied to the fan coil unit (FCU) and AHU, which operates each section in charge. Currently, the heat sources system is controlled automatically. Both the GHP and ABS chiller-heater are operated by a numerical control system based on the hot and cold supply temperature. On the other hand, when the building load is very low, all heat sources systems operate to meet the set temperature and help reduce the problem of energy wastage.

Table 2. Room conditions.

\begin{tabular}{cccccc}
\hline \multirow{2}{*}{ Classification } & \multicolumn{2}{c}{ Temperature $\left({ }^{\circ} \mathbf{C}\right)$} & & \multicolumn{2}{c}{ Humidity (\%) } \\
\cline { 2 - 3 } \cline { 5 - 6 } & Summer & Winter & & Summer & Winter \\
\hline Ward department & 26 & 23 & & 55 & 45 \\
Department of pharmacy & 26 & 22 & & 55 & 45 \\
Outpatient department & 26 & 22 & & 55 & 45 \\
Operating room & 24 & 24 & & 50 & 50 \\
Recovery room & 24 & 25 & & 55 & 50 \\
Office & 26 & 20 & & 55 & 45 \\
Assembly hall & 26 & 20 & & 55 & 45 \\
\hline
\end{tabular}

As shown Figure 3, the GHP system of the building is a water-to-water GHP system. An underground heat exchanger is installed in a depth of $169 \mathrm{~m}$, and the number of drilling holes is 140. Table 3 shows the equipment list of the geothermal heat pump system. Table 4 shows the schedule of the absorption chiller-heater equipment. 


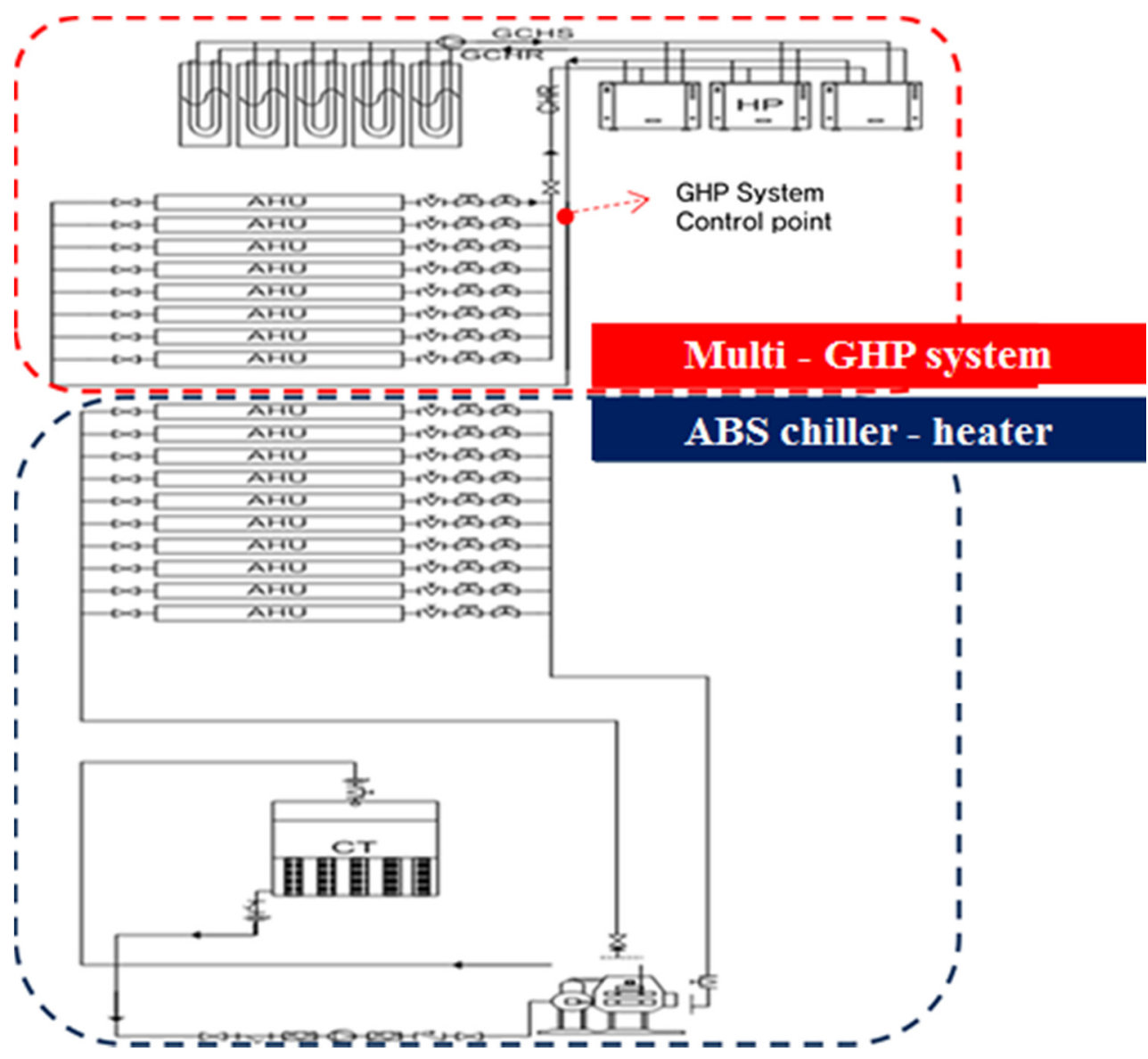

Figure 2. Schematic diagram of the operation of the target building.

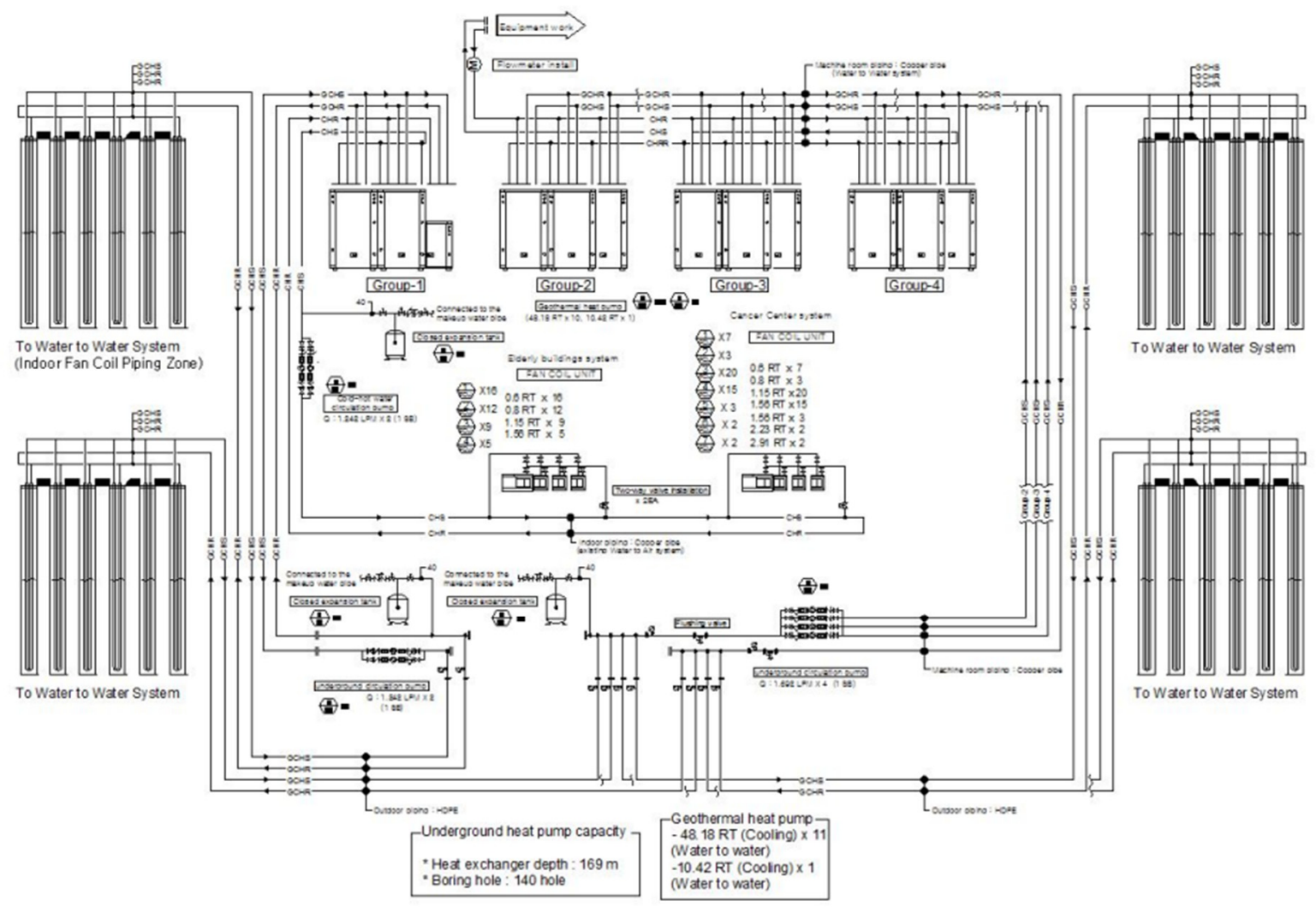

Figure 3. Schematic diagram of the GHP system. 
Table 3. Multi-GHP system information.

\begin{tabular}{ccccc}
\hline Equipment number & \multicolumn{2}{c}{ GH-1 } & \multicolumn{2}{c}{ GH-2 } \\
\hline Quantity & \multicolumn{2}{c}{11} & \multicolumn{2}{c}{1} \\
\hline Capacity $(\mathbf{G J} / \mathbf{h})$ & Cooling & Heating & Cooling & Heating \\
& 0.59 & 0.62 & 0.12 & 0.13 \\
\hline Entering source temperature (EST) $\left({ }^{\circ} \mathbf{C}\right)$ & 31 & 5 & 31 & 5 \\
\hline Supplied temperature $\left({ }^{\circ} \mathbf{C}\right)$ & 7 & 45 & 7 & 45 \\
\hline Return water temperature $\left({ }^{\circ} \mathbf{C}\right)$ & 12 & 40 & 12 & 40 \\
\hline
\end{tabular}

Table 4. Absorption (ABS) chiller-heater information.

\begin{tabular}{ccccc}
\hline Equipment number & \multicolumn{2}{c}{ DAC H-1 } & \multicolumn{2}{c}{ DAC H-2 } \\
\hline Quantity & \multicolumn{2}{c}{3} & \multicolumn{2}{c}{1} \\
\hline \multirow{2}{*}{ Capacity $(\mathbf{G J} / \mathbf{h})$} & Cooling & Heating & Cooling & Heating \\
& 10.13 & 10.13 & 6.33 & 6.33 \\
\hline \multirow{2}{*}{ Cool water $\left({ }^{\circ} \mathbf{C}\right)$} & Inlet & Outlet & Inlet & Outlet \\
& 12 & 7 & 12 & 7 \\
\hline Hot water $\left({ }^{\circ} \mathbf{C}\right)$ & 55 & 60 & 55 & 60 \\
\hline Coolant $\left({ }^{\circ} \mathbf{C}\right)$ & 32 & 37.5 & 32 & 37.5 \\
\hline
\end{tabular}

\section{Development of the Hybrid Operation Method}

\subsection{Multi-Geothermal Heat Pump (Multi-GHP) System}

The power capacity demand of a Korean summer is increased due to the increased power demand from air conditioners. On the other hand, there has been a lack of research on reducing the cooling loads to improve the energy efficiency of buildings. In addition, the existing operation plan has a problem with the super cooling phenomenon in buildings due to oversized design of the AHU fan air flow rate, resulting in a waste of energy. This study focused on reducing the air cooling load and developing a new algorithm. The existing operation of a GHP system control method was proposed and evaluated to improve the energy efficiency.

\subsubsection{Existing Operation Condition of the Multi-Geothermal Heat Pump (Multi-GHP System) (Case 1-1)}

As shown in Figure 4a, the problem with the existing operation method was attributed to oversizing of the AHU fan airflow. Therefore, the room temperature could not be maintained at the set temperature $\left(24 \pm 1^{\circ} \mathrm{C}\right)$. To solve this, Case 1-1 was set up to reset the fan airflow according to the summer cooling load using Equation (1). Table 5 shows the resetting of the fan air flow rate. As a result the room temperature was controlled according to the set temperature as shown in the Figure $4 \mathrm{~b}$ :

$$
m=\frac{Q_{\max }}{C \Delta T}
$$

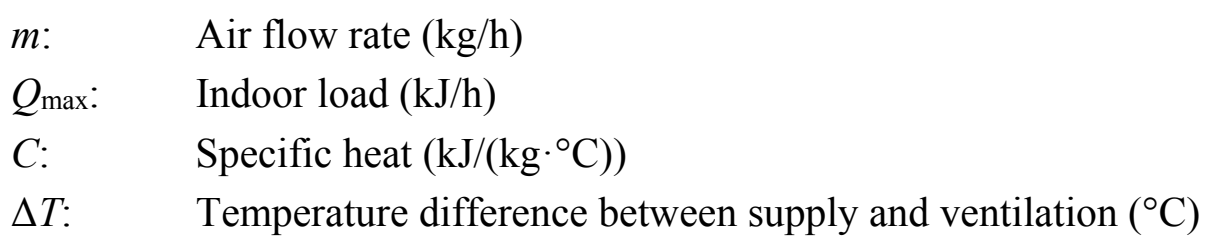




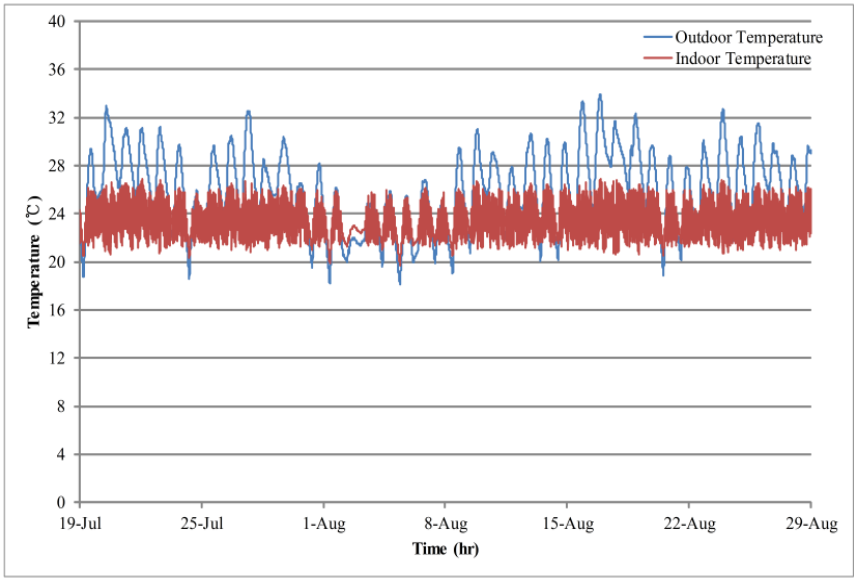

(a)

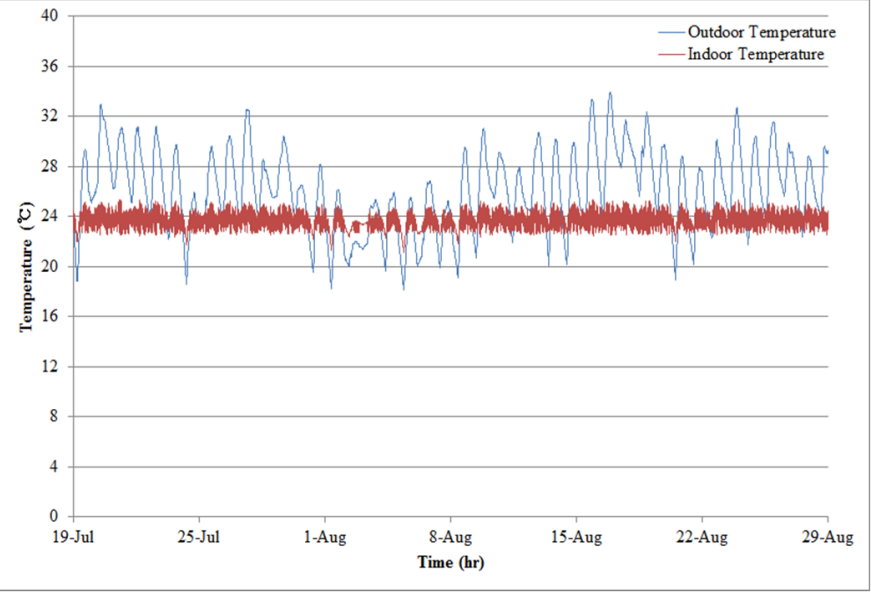

(b)

Figure 4. Existing operation condition of a room indoor temperature graph (Case 1-1): (a) design air flow rate set point; (b) reset of air flow rate set point.

Table 5. Reset the air handling unit (AHU) fan air flow rate.

\begin{tabular}{cccccccc}
\hline Unit: $\mathbf{~ k g} / \mathbf{h}$ & AHU1 & AHU2 & AHU3 & AHU4 & AHU5 & AHU6 & AHU8 \\
\hline Design air flow rate & 51,840 & 19,200 & 32,640 & 49,200 & 38,400 & 25,200 & 36,000 \\
Reset air flow rate & 42,000 & 24,000 & 14,000 & 27,000 & 28,000 & 17,000 & 24,000 \\
\hline
\end{tabular}

Control of the Multi-GHP system and ABS chiller-heater of the building is accomplished by considering the load side returns water temperature. The cold water outlet temperature of the Multi-GHP system and $\mathrm{ABS}$ chiller-heater is operated to maintain a set point of $7^{\circ} \mathrm{C}\left(T_{\text {set }}\right)$ in summer. That is, when the cold water outlet temperature is lower than the set value $\left(7^{\circ} \mathrm{C}\right)$, the GHP system ABS chiller operation is stopped and if not less than $7{ }^{\circ} \mathrm{C}$, the heat source system is on/off operated. A heat source system is constructed to match the load temperature setting. Accordingly, the heat source system is operated under on/off control. On the other hand, even if there is no load on the AHU space, energy is unnecessarily consumed to meet the chilled water set point temperature. Without limiting the water temperature set point to solve this problem, it is important that an operation method be used to reduce the wasted energy.

In addition, the Multi-GHP system and ABS chiller-heater are responsible for a fixed number of AHU. Therefore, the existing operations of the target building are separated independently, i.e., the Multi-GHP system and ABS chiller-heater. In this way, all heat source systems will be operated, even if the load of the building satisfies the efficient GHP only. As a result, energy wastage will occur. Figure 5 presents the existing operating status control algorithm. 


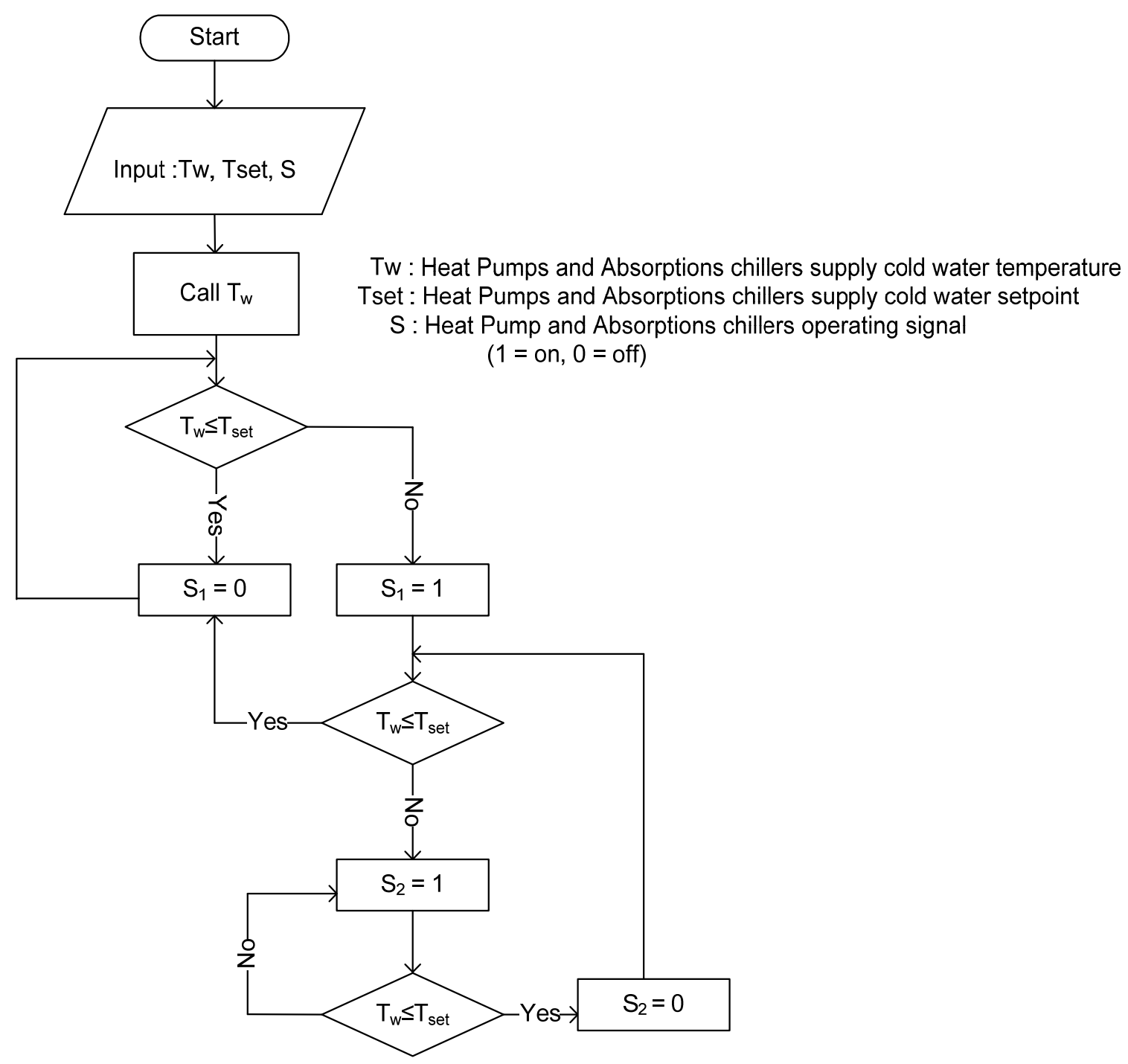

Figure 5. Control algorithms of the existing operating condition (Case 1-1).

(1) Multi-GHP system and ABS chiller-heater are not operating.

- Activate the heat pump if it is higher than the set temperature of the heat source system water outlet temperature $\left(T_{\mathrm{w}}>T_{\text {set }}\right)$. Determine the operation of the heat source system, depending on the set temperature.

- The heat source system maintains the present condition if the cold water outlet temperature is not less than $7{ }^{\circ} \mathrm{C}$.

(2) Multi-GHP system and ABS chiller-heater are operating.

- When the heat source system cold water outlet temperature is lower than the set point $\left(7^{\circ} \mathrm{C}\right)$, stop the heat source system operation.

- To match the set temperature, when the heat pump cold water outlet temperature is higher than the set point $\left(7^{\circ} \mathrm{C}\right)$, operate the next heat source system. The heat source system stops operation sequentially when the set temperature is lower than the cold water outlet temperature of the heat source system. 


\subsubsection{Sequencing Operation Condition of the Multi-Geothermal Heat Pump (Multi-GHP) System} (Case 1-2)

The existing method, regardless of the outside temperature, is operated when the AHU and heat pump to the load side of the return temperature are fixed to $7{ }^{\circ} \mathrm{C}$. On the other hand, the temperature return of the load side results in unnecessary energy consumption. Therefore, as shown in Table 6 , an operation plan was proposed to increase the efficiency of the heat pump system by reducing the energy consumption.

Table 6. Summary of the operation cases of the Multi-GHP system.

\begin{tabular}{cc}
\hline Case 1 & Classification \\
\hline Case 1-1 & Existing operation condition of Multi-GHP system \\
Case 1-2 & Sequencing operation condition of Multi-GHP system \\
\hline
\end{tabular}

The return temperature control in the GHP can cause problems with the indoor comfort or cause a waste of energy. This is because the Multi-GHP system is operated regardless of the load in the indoor space. Therefore, if the room temperature fails to conform to a set temperature of $24{ }^{\circ} \mathrm{C}$, a control method is proposed to operate the heat pump by adding one each. Figure 6 presents algorithms of the sequencing operation according to the room temperature. If a heat pump is operating in sequence through indoor temperature monitoring, the Multi-GHP system can be operated to match the actual load. In addition, the Multi-GHP system can be operated to reduce the waste of energy and improve the room comfort.

(1) Multi-GHP system is not operating.

- Activate the heat pump when the temperature is higher than the set temperature of the AHU space temperature $\left(T_{\text {room }}>T_{\mathrm{r} \text {,set }}\right)$. The heat pump is operated sequentially upon failure to share the load of the room with a single heat pump. The ABS chiller-heater is operated upon failure to share the load with all heat pumps.

- The Multi-GHP system maintains the present condition if the AHU space temperature is the set point temperature.

(2) Multi-GHP system is operating.

- When the room temperature is lower than the set point ( $T_{\text {room }} \leq T_{\text {r,set }}$ ), stop the sequentially Multi-GHP system operation.

- To match the set temperature, when air condition room temperature is higher than the set point temperature, operate the next the Multi-GHP system additionally $\left(T_{\text {room }}>T_{\text {r,set }}\right)$. 


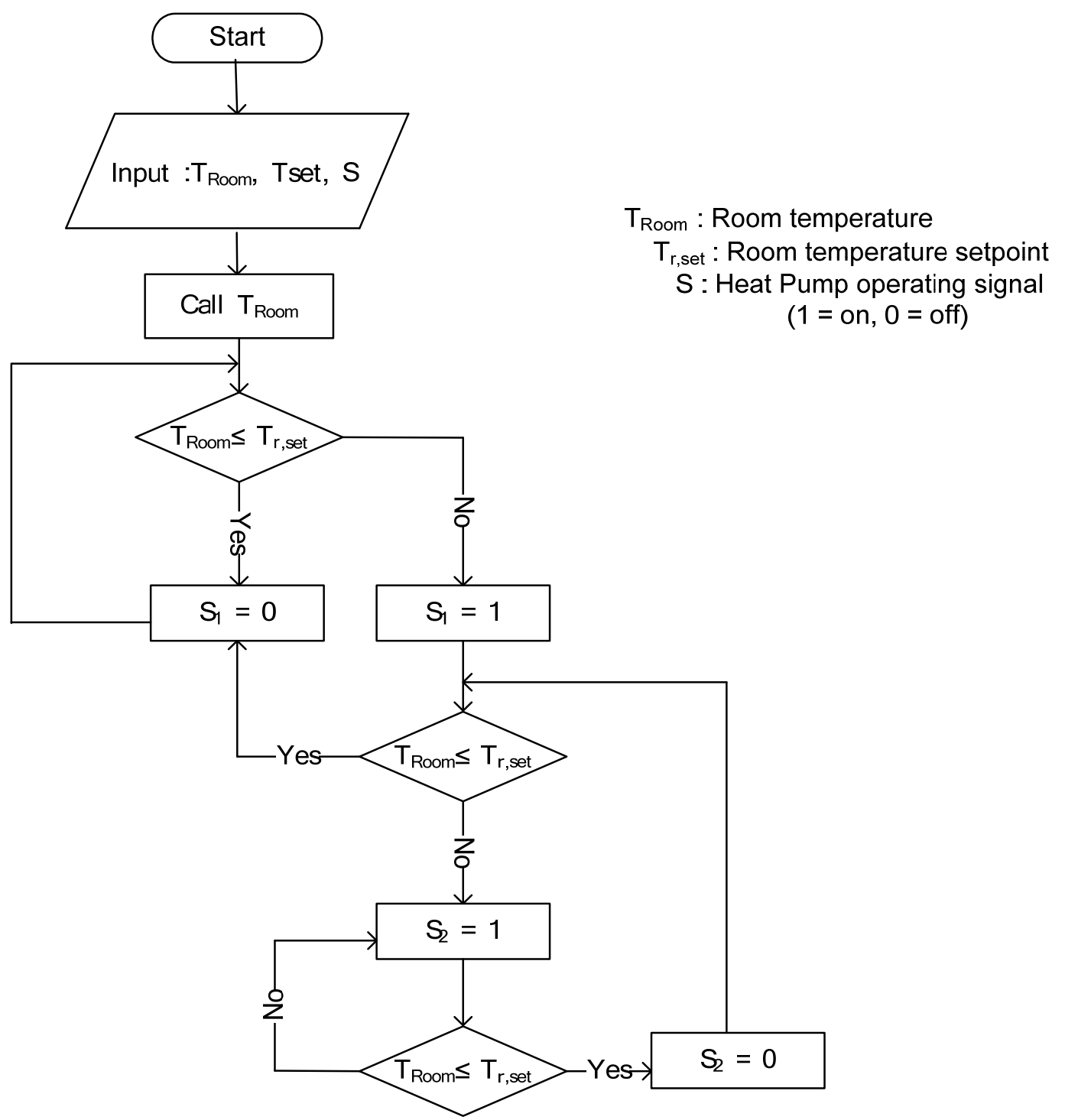

Figure 6. Control algorithms of the sequencing operation condition of the Multi-GHP system.

3.2. Combination with Multi-Geothermal Heat Pump (Multi-GHP) System and an Absorption (ABS) Chiller-heater System

The Multi-GHP system and ABS chiller-heater are separated independently from the existing operation of this building being used. As shown in Table 7, the operation method was proposed to be used in combination with the ABS chiller-heater and Multi-GHP systems while maximizing the use of the heat pump systems. The energy consumption was compared using two types of case.

Table 7. Summary of the operation cases of a combination with the Multi-GHP systems and the ABS chiller-heater system.

\begin{tabular}{cc}
\hline Case 2 & Classification \\
\hline Case 2-1 & $\begin{array}{r}\text { Existing operation condition of the Multi-GHP systems } \\
\text { and the ABS chiller-heater system }\end{array}$ \\
Case 2-2 & $\begin{array}{r}\text { Hybrid operation condition of the Multi-GHP systems } \\
\text { and the ABS chiller-heater system }\end{array}$ \\
\hline
\end{tabular}


3.2.1. Existing Operation Condition of the Multi-Geothermal Heat Pump (Multi-GHP) Systems and the Absorption (ABS) Chiller-heater System (Case 2-1)

The Multi-GHP system and ABS chiller-heater are responsible for a fixed number of AHU. Therefore, existing operations of the target building are separated independently; the Multi-GHP system and ABS chiller-heater. In this way, even if the load of the building satisfies only the efficient GHP, all heat source systems will be operated. As a result, energy wastage occurs.

3.2.2. Hybrid Operation Condition of the Multi-Geothermal Heat Pump (Multi-GHP) Systems and the Absorption (ABS) Chiller-heater System (Case 2-2)

Among them, the higher efficiency of the Multi-GHP system is selected and integrated with the ABS chiller-heater. In other words, a control method is proposed for the hybrid system design of the Multi-GHP system with an ABS chiller-heater. If the operation of the Multi-GHP system is maximized and the ABS chiller-heater, i.e., the existing heat source, is minimized, this would result in an increase in energy efficiency. Figure 7 presents the control algorithm.

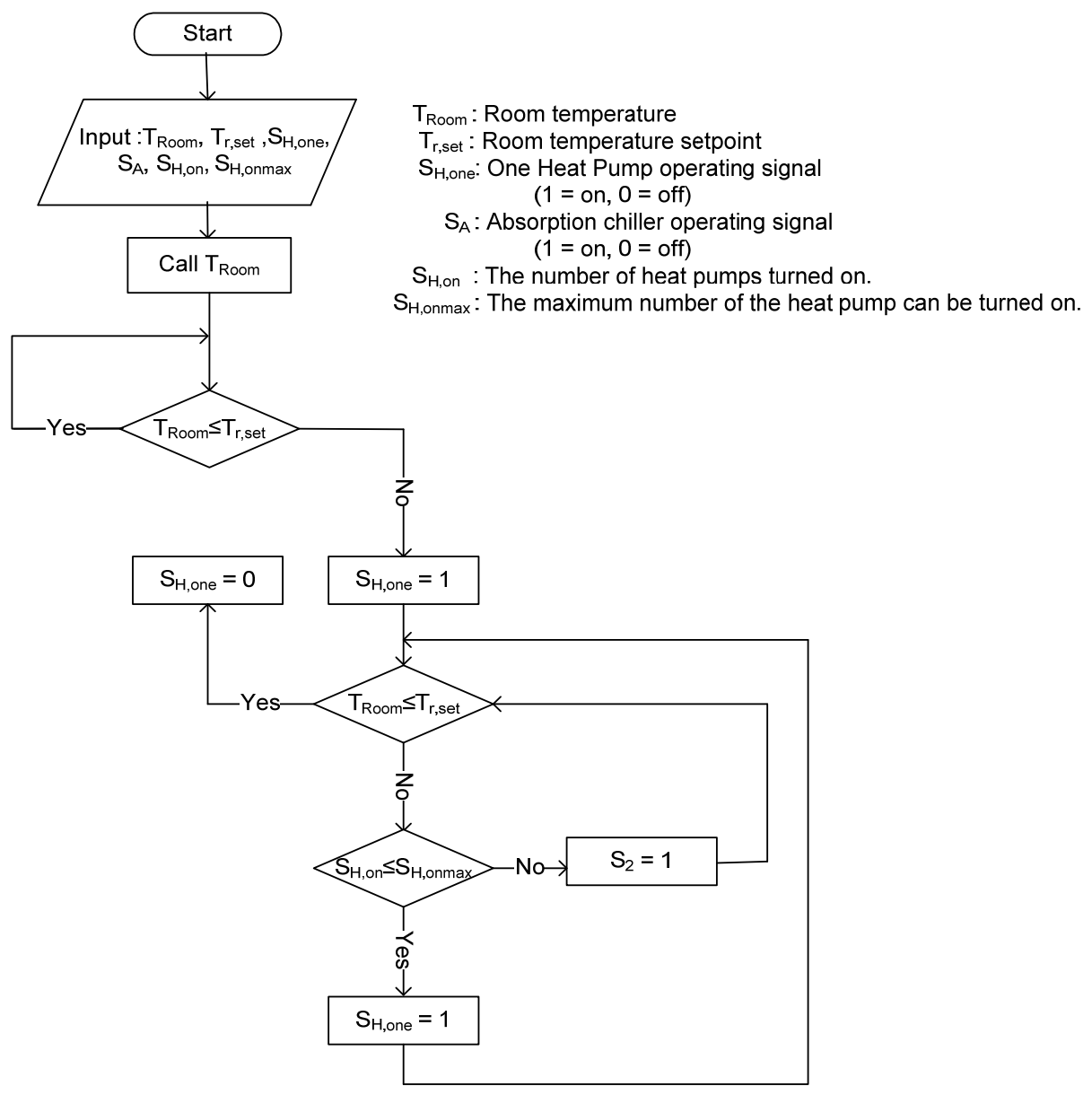

Figure 7. Hybrid operation method of the Multi-GHP system and ABS chiller-heater system.

(1) Multi-GHP system is not operating.

- Activate the heat pump when the temperature is higher than the set temperature of the AHU space temperature ( $\left.T_{\text {room }}>T_{\mathrm{r}, \text { set }}\right)$. The heat pump is operated sequentially upon failure to share 
the load of a room with a single heat pump. The ABS chiller-heater is operated upon failure to share the load with all heat pumps.

(2) Multi-GHP system is operating.

- When the room temperature is lower than the set point ( $\left.T_{\text {room }} \leq T_{\text {r,set }}\right)$, stop the sequentially Multi-GHP system operation.

- To match the set temperature, when air condition room temperature is higher than the set point temperature, operate the next Multi-GHP system additionally ( $\left.T_{\text {room }}>T_{\mathrm{r}, \mathrm{set}}\right)$.

- If the maximum heat pump operation cannot bear the load, activate the ABS chiller-heater.

\section{Simulations and Results}

\subsection{Simulation Information}

Building modeling was performed, as shown in Figure 8, using the transient system simulation program (TRNSYS) 3D of Google Sketch-Up. As shown in Figures 9 and 10, detailed data was entered into the target building via Trnbuild modeling and TRNSYS Studio modeling, the HVAC system was implemented. The weather data is from Daegu, Korea. Table 8 shows the components and properties of each wall. In addition, the hospital building heat source equipment operates in the facility $24 \mathrm{~h}$ a day.

Table 8. Material property specifications.

\begin{tabular}{|c|c|c|c|c|}
\hline Classfication & Construction & Thick (m) & Conductivity (W/mK) & Density $\left(\mathrm{kg} / \mathrm{m}^{3}\right)$ \\
\hline \multirow{4}{*}{ Exterior wall } & Granite & 0.03 & 3.17 & 2560 \\
\hline & panel & 0.1 & 0.51 & 140 \\
\hline & Insulation & 0.042 & 0.036 & 140 \\
\hline & Gypboard & 0.025 & 0.58 & 800 \\
\hline \multirow{3}{*}{ Interior wall } & Gypboard & 0.016 & 0.16 & 801 \\
\hline & Air & 0.022 & - & - \\
\hline & Gypboard & 0.016 & 0.16 & 801 \\
\hline \multirow{2}{*}{ Floor } & Concrete & 0.2 & 1.6 & 2240 \\
\hline & Insulation & 0.061 & 0.051 & 140 \\
\hline
\end{tabular}

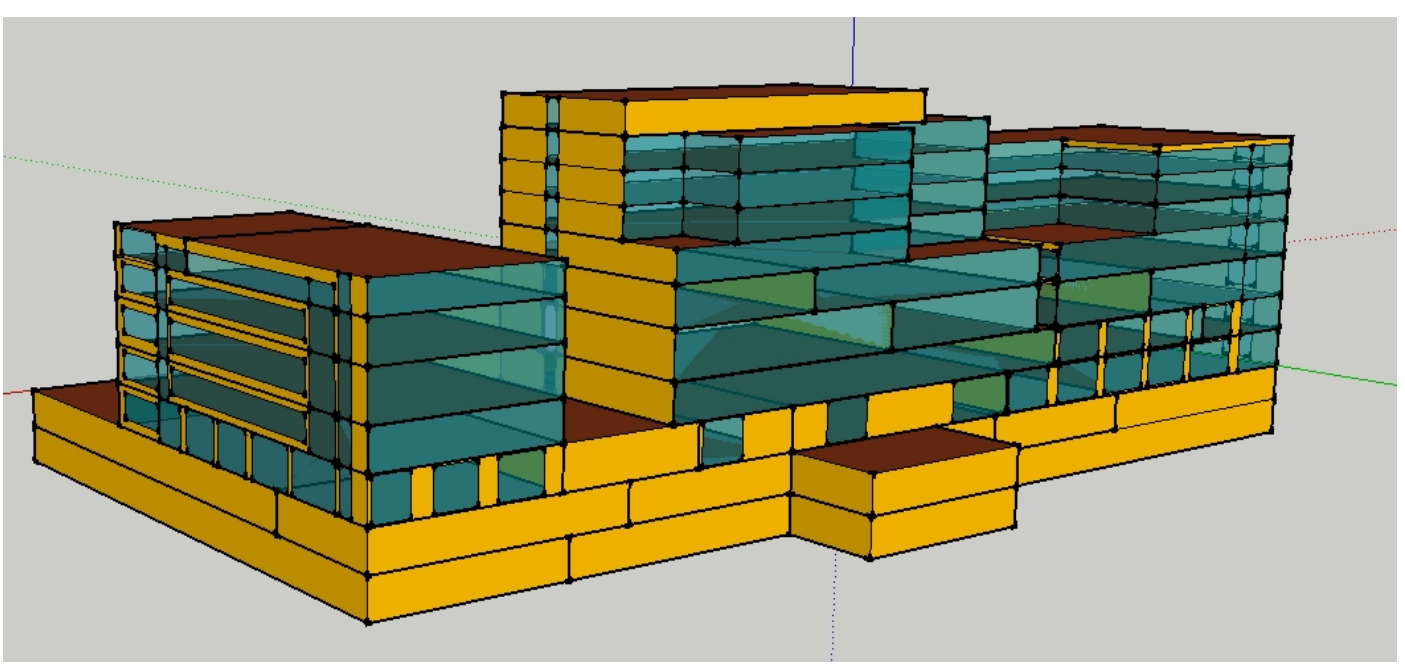

Figure 8. Building modeling using the sketch up program. 


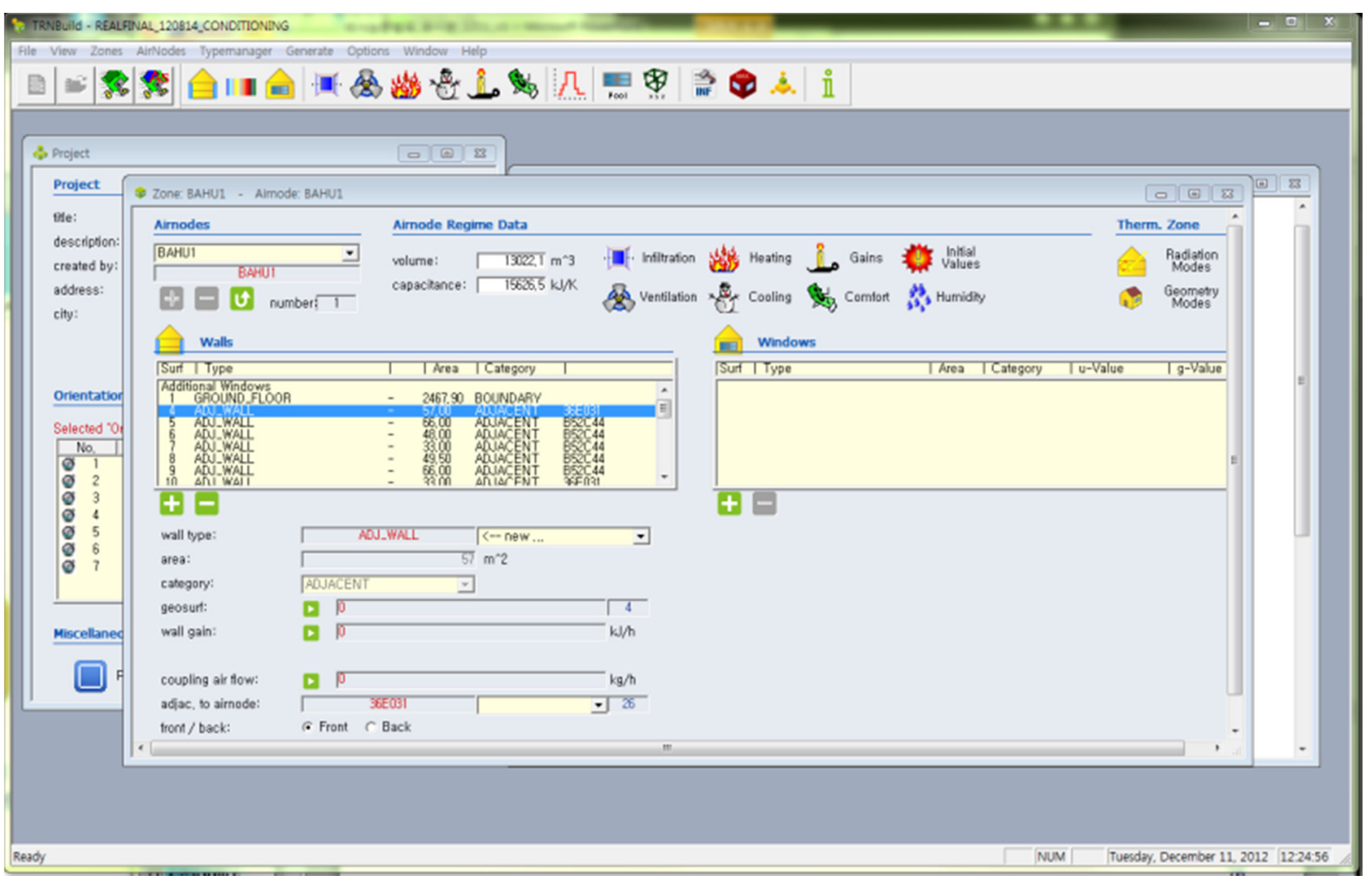

Figure 9. Trnbuild modeling.

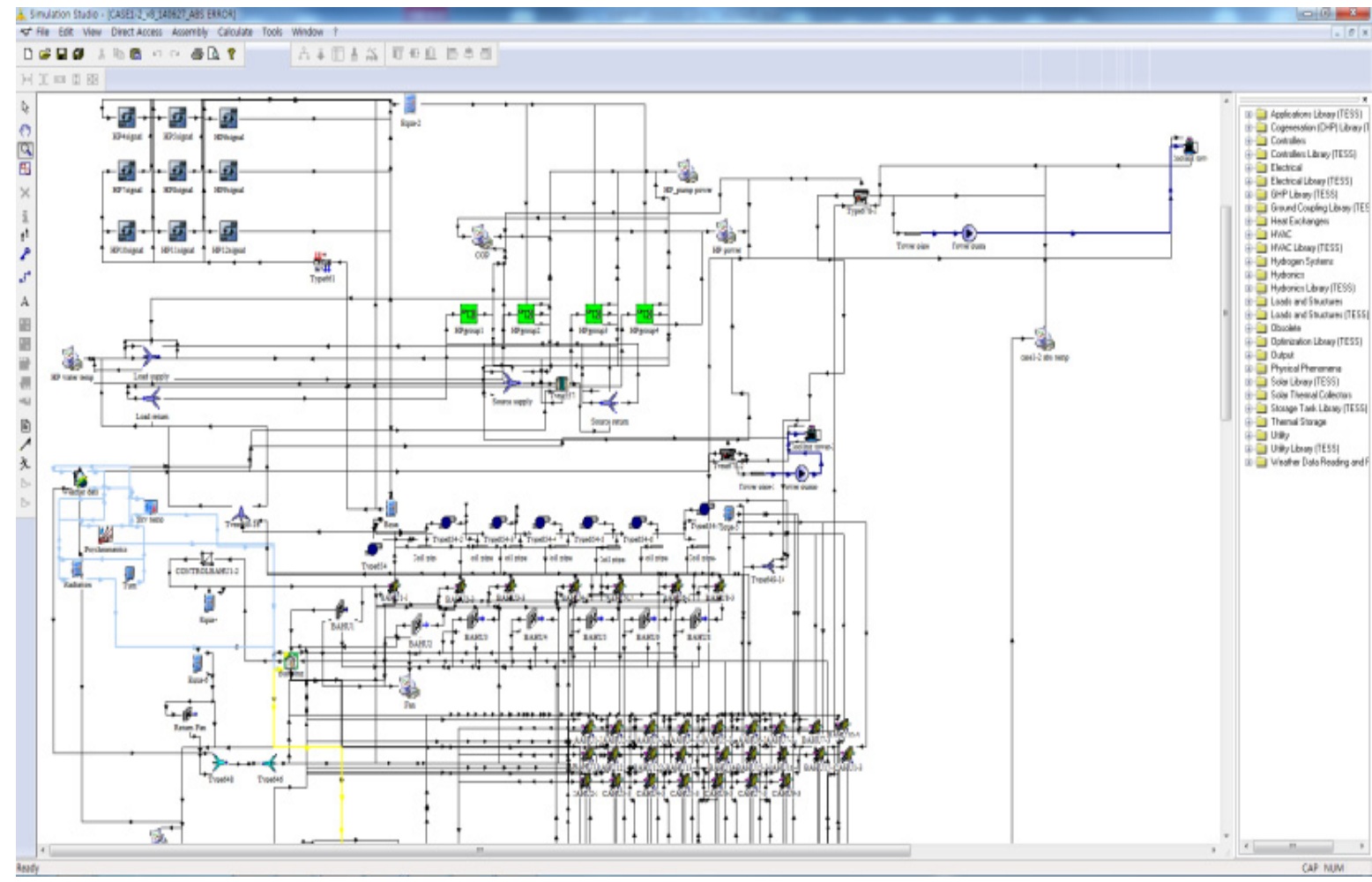

Figure 10. Transient system simulation program (TRNSYS) simulation studio modeling.

\subsubsection{Building Modeling}

The aim of this study was to show the operation method of the Multi-GHP system can improve the energy efficiency through the TRNSYS simulation, as shown in Figures 11 and 12 [31]. 


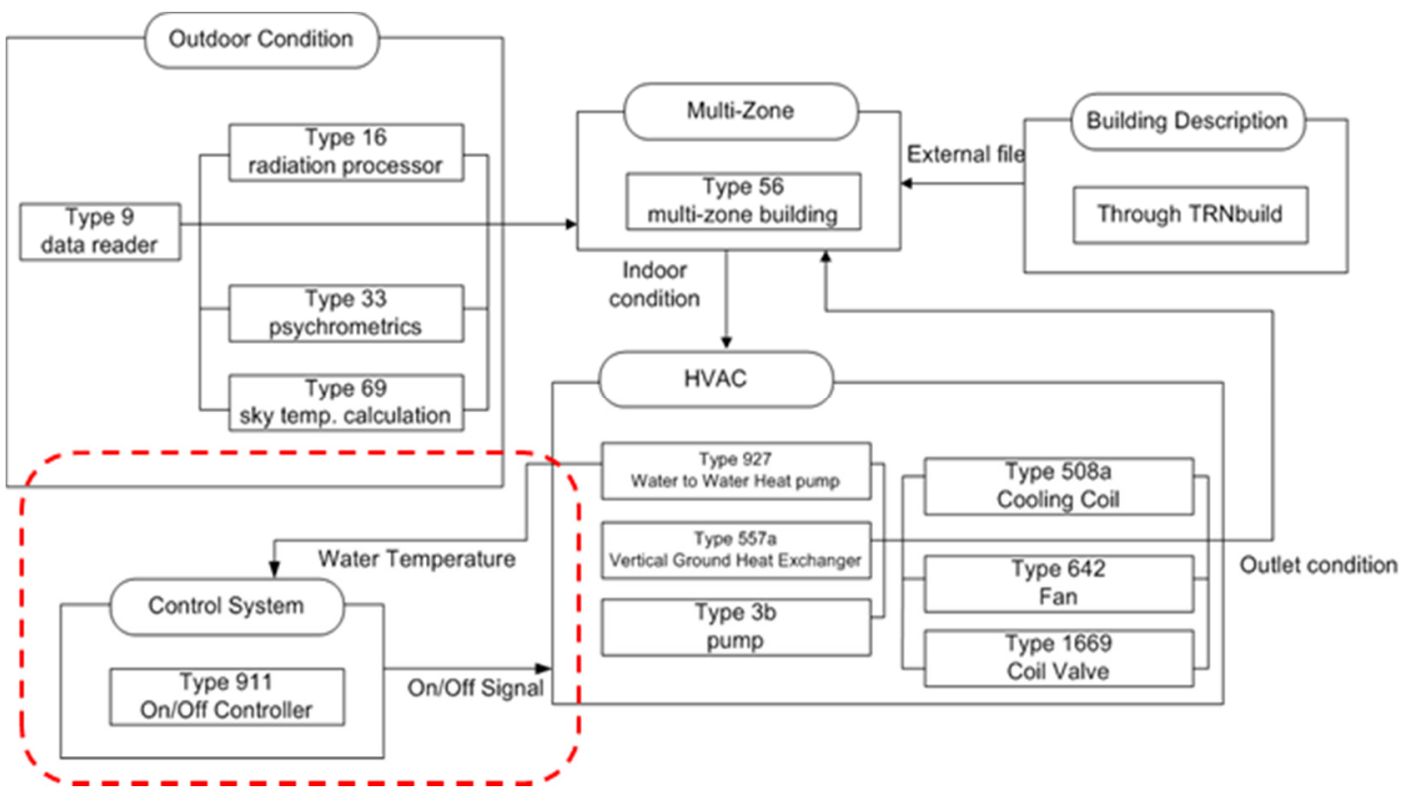

(a)

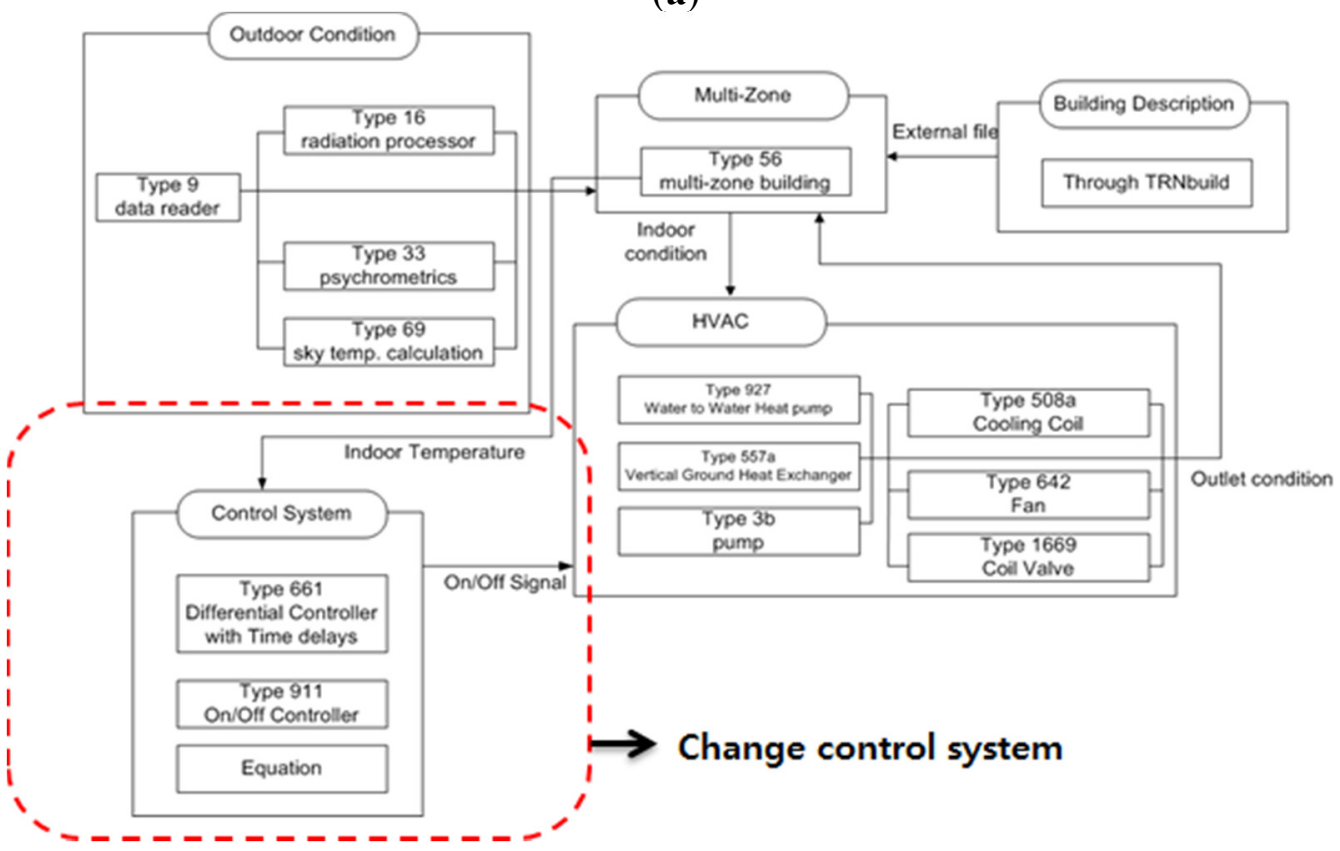

(b)

Figure 11. Simulation flow chart of the Multi-GHP system: (a) existing operation condition of Multi-GHP system (Case 1-1); (b) sequencing operation condition of Multi-GHP system (Case 1-2).

In the case of water to the water heat pump, a Type 927 (water to water heat pump) was used. A Type $557 \mathrm{a}$ is a vertical ground heat exchanger. The set point temperature control of the Multi-GHP system used a Type 911 of on/off controller. The proposed heat pump that implemented the sequencing control according to the room temperature was connected to the control system of an existing operating system. For Case 1-2, the implemented outdoor reset control connects to the control system of an existing to the control system of an existing operating system from the outside temperature. In addition, the proposed heat pump used a Type 661 device for the time delay and reflected the ambient temperature, which was performed sequentially using the equation for control. 
Case 2-1 is the existing operating method for the separate ABS chiller-heater and Multi-GHP system. The Type 678 (absorption chiller) and Type 700 (gas boiler) of TRNSYS were used in the case of the ABS chiller-heater. Figure 12a presents a schematic diagram of the simulation. As shown in Figure 12b, Case 2-2, which was simulated by modeling a single system, combines the ABS chiller-heater and a Multi-GHP system that is separated and independent.

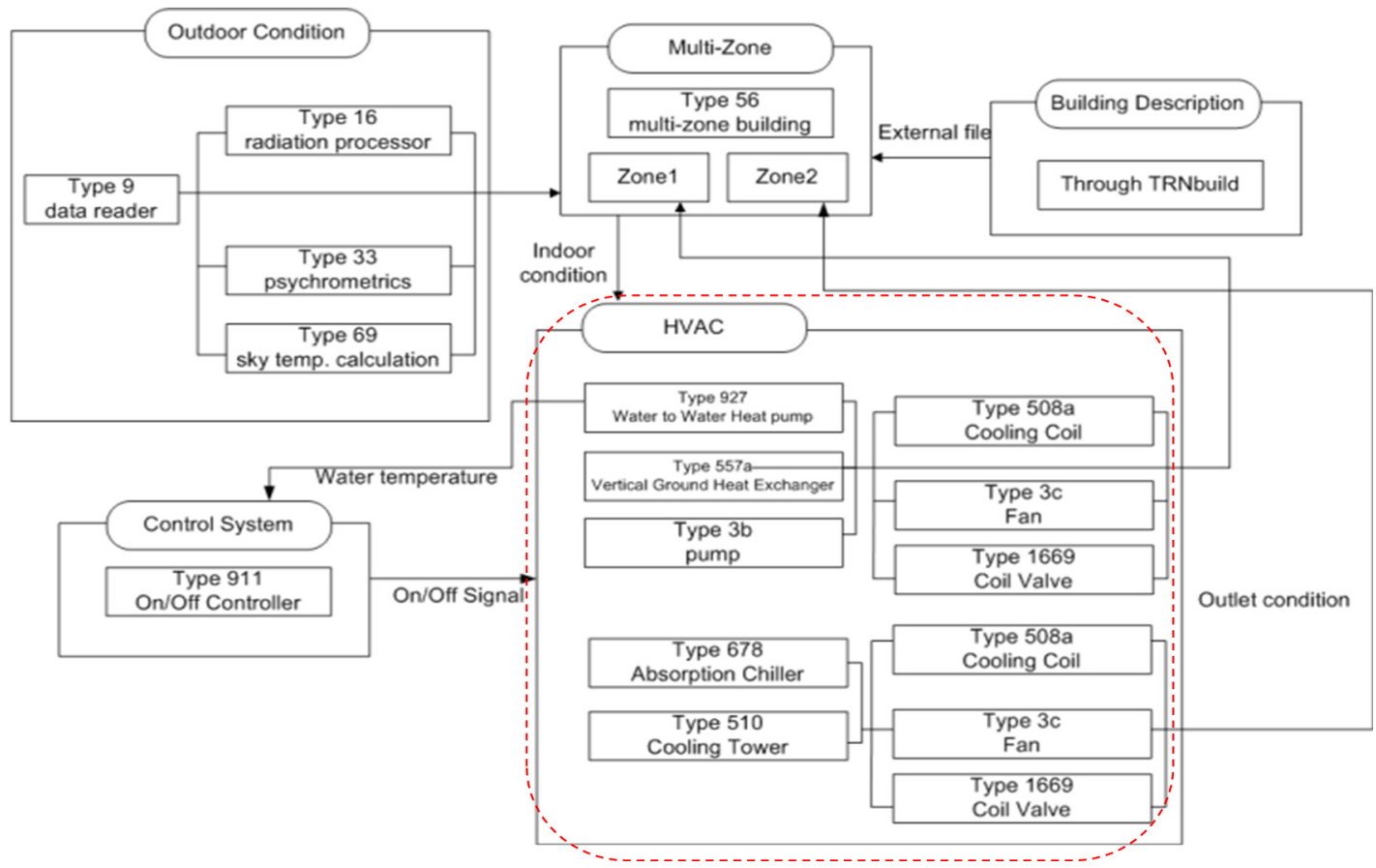

(a)

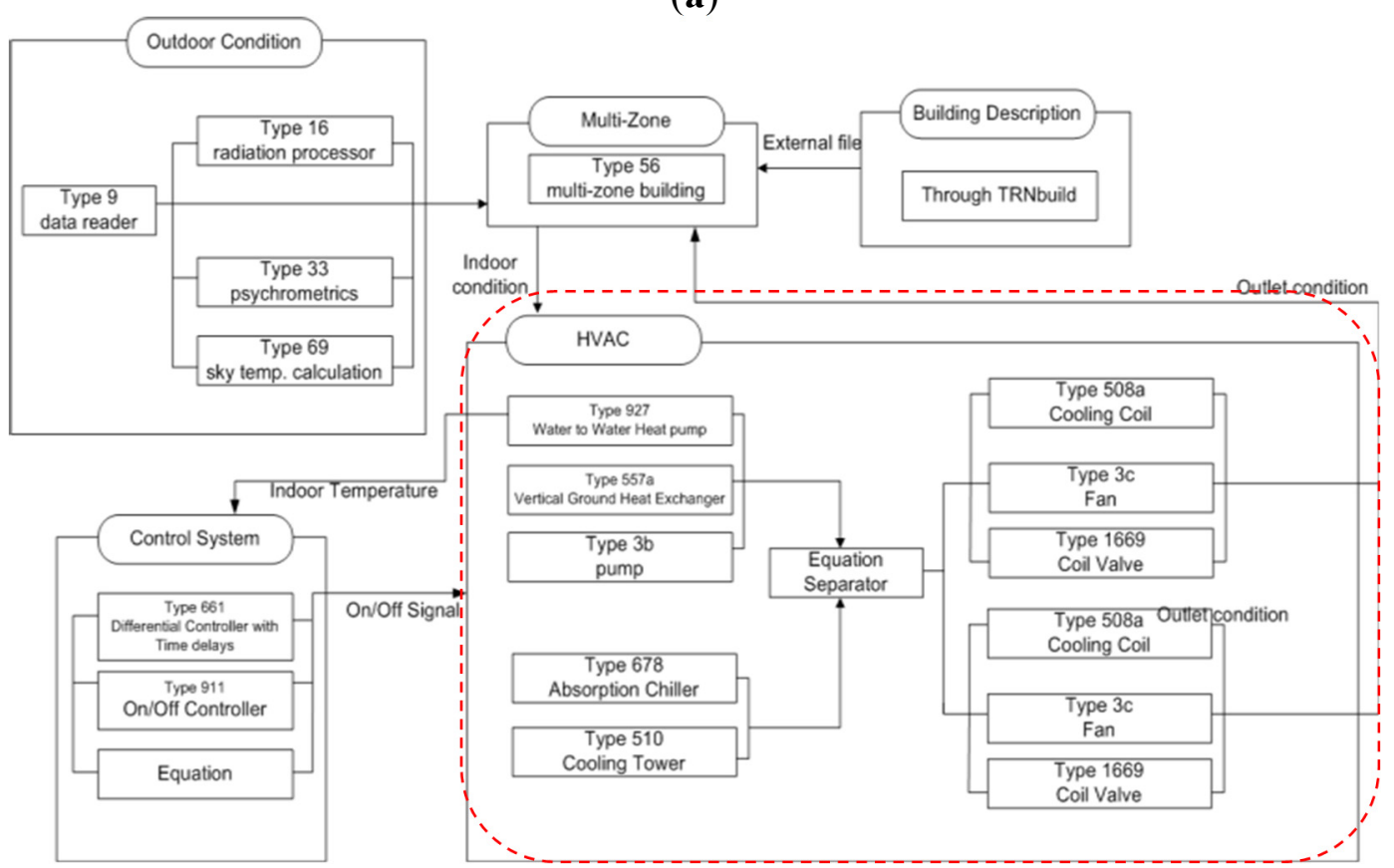

(b)

Figure 12. Simulation flow chart of a combination with the Multi-GHP system and an ABS chiller-heater system: (a) existing operation condition of the Multi-GHP system and ABS chiller-heater system (Case 2-1); (b) sequencing operation condition of the Multi-GHP system and ABS chiller-heater system (Case 2-2). 


\subsubsection{Simulation Validation}

According to Equations (2)-(5), mean bias error $(M B E)$ and coefficient of variation of root mean square error $\left(C_{\mathrm{v}}(R M S E)\right)$, which is one of the statistical methods compared to the actual data, were used to evaluate the results of the simulations. The corresponding equations are as follows:

$$
\begin{gathered}
M B E(\%)=\frac{\sum_{\text {Period }}(S-M)_{\mathrm{INT}}}{\sum_{\text {Period }} M_{\mathrm{INT}}} \times 100 \\
S E_{\text {Period }}=\sqrt{\frac{\sum(S-M)_{\mathrm{INT}}^{2}}{N_{\mathrm{INT}}}} \\
A_{\text {Period }}=\frac{\sum_{\text {Period }} M_{\mathrm{INT}}}{N_{\mathrm{INT}}} \\
C_{\mathrm{V}}\left(S E_{\text {Peiod }}\right)=\frac{S E_{\text {Period }}}{A_{\text {Period }}} \times 100
\end{gathered}
$$

where:

$S_{\text {INT: }} \quad$ Simulation data $(\mathrm{kWh})$

MINT: $\quad$ Actual data $(\mathrm{kWh})$

NINT: $\quad$ The total number of actual data

According to the ASHRAE Guideline 14 [32], the simulation results of the building are reliable if the results entered in the range of Table 9 are comparable to the actual data results. The actual target for the building's electricity usage in August was approximately 348,682 $\mathrm{kWh}$, and a simulation of the electricity usage was approximately $337,283 \mathrm{kWh}$. This result compares well with the value of the simulation and actual power capacity; the simulation value was calculated to be $96.7 \%$ of that actually measured. In other words, the MBE value was approximately $-3.27 \%$ and the $C_{\mathrm{v}}$ (RMSE) values were approximately $10.83 \%$. Therefore, the results of the simulations can be considered as accurate.

Table 9. Simulation validation result.

\begin{tabular}{cccc}
\hline Calibration type & Index & Acceptable value & Result \\
\hline \multirow{2}{*}{ Monthly } & MBE month & $\pm 5 \%$ & $-3.27 \%$ \\
& $C_{\mathrm{v}}$ (RMSE month) & $15 \%$ & $10.83 \%$ \\
\hline
\end{tabular}

\subsection{Simulation Result}

\subsubsection{Operation Cases of the Multi-Geothermal Heat Pump (Multi-GHP) System}

Figure 13 shows the room temperature when the indoor temperature is set to $24{ }^{\circ} \mathrm{C}\left( \pm 1{ }^{\circ} \mathrm{C}\right)$ in the summer. Figure 14 shows the room temperature when the indoor temperature is set to $24{ }^{\circ} \mathrm{C}\left( \pm 1^{\circ} \mathrm{C}\right)$ in the winter. Even if the set temperature of the room is only slightly out, the occupants are uncomfortable. The results of the simulations were verified in all cases setting a range of set temperatures of the room. For Case 1-1 the summer room temperature is as follows: average room temperature is $23.6{ }^{\circ} \mathrm{C}$, maximum temperature $25.35^{\circ} \mathrm{C}$ and minimum temperature $21.13{ }^{\circ} \mathrm{C}$. Case $1-2$ average room temperature 
is $23.88{ }^{\circ} \mathrm{C}$, maximum temperature $25.62{ }^{\circ} \mathrm{C}$ and minimum temperature $21.17^{\circ} \mathrm{C}$. Case $1-1$ winter room temperature is as follows: average room temperature is $23.67{ }^{\circ} \mathrm{C}$, maximum temperature $25.58{ }^{\circ} \mathrm{C}$ and minimum temperature $22.08^{\circ} \mathrm{C}$. Case $1-2$ average room temperature is $23.68^{\circ} \mathrm{C}$, maximum temperature $25.44{ }^{\circ} \mathrm{C}$ and minimum temperature $23.53{ }^{\circ} \mathrm{C}$.

In Cases 1-1 and 1-2, the Multi-GHP system existing operation method and ABS chiller-heater systems were separated. Case 2-1 and 2-2, applying the operation method of Case 2 of a high efficiency heat pump, are a combined method Multi-GHP system and ABS chiller-heater system. First of all, after the high efficiency Multi-GHP systems are used, the ABS chiller-heater systems are operated if the GHP only is not in charge of the load. As listed in Table 10, the room temperature approached the set point more with Cases 1-1 and 1-2 than with Case 2, and the room temperature variation was reduced. Accordingly, the indoor thermal environment control was comfortable and stable.

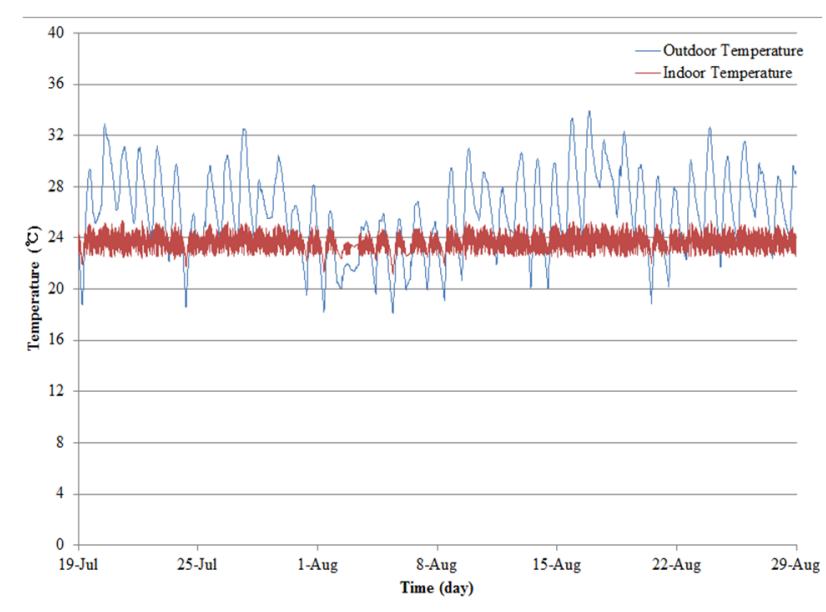

(a)

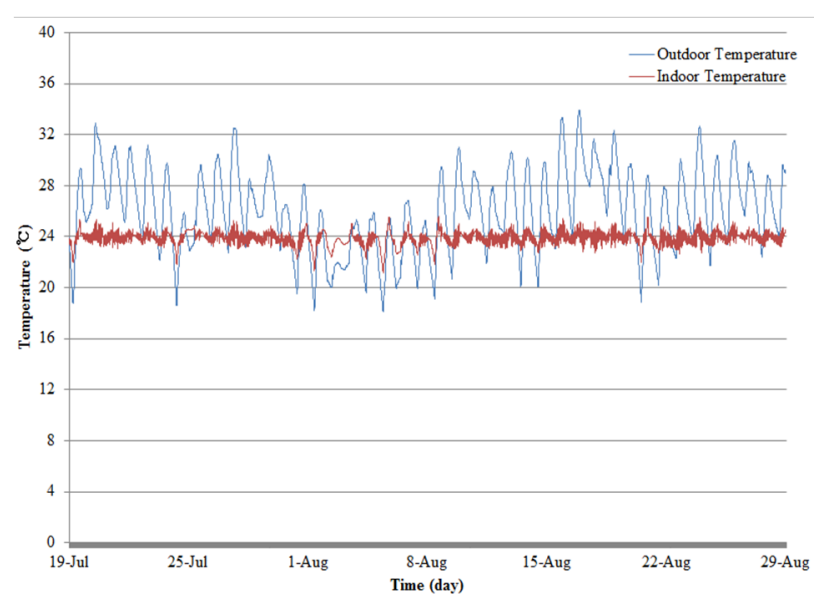

(b)

Figure 13. Indoor environment conditions of the Multi-GHP system in the summer: (a) existing operation condition of Multi-GHP system (Case 1-1); (b) sequencing operation condition of Multi-GHP system (Case 1-2).

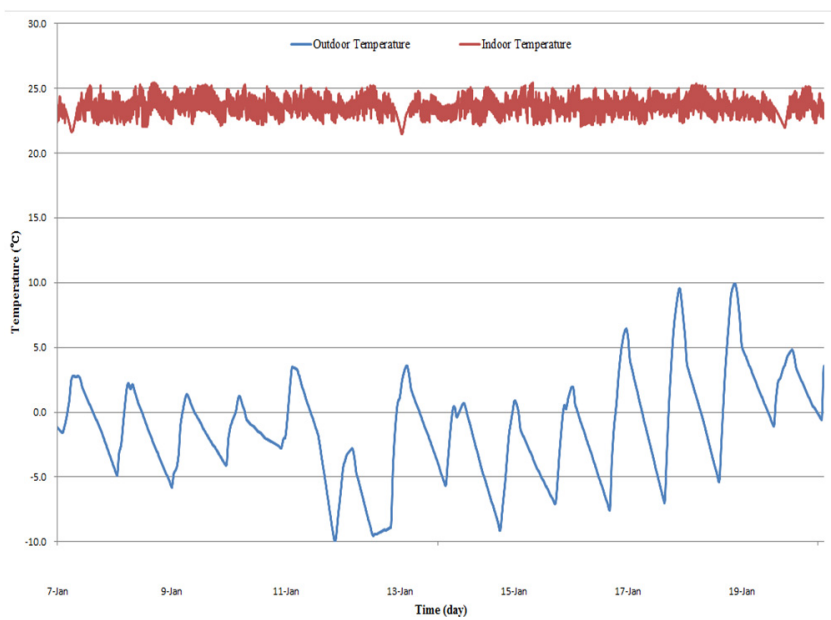

(a)

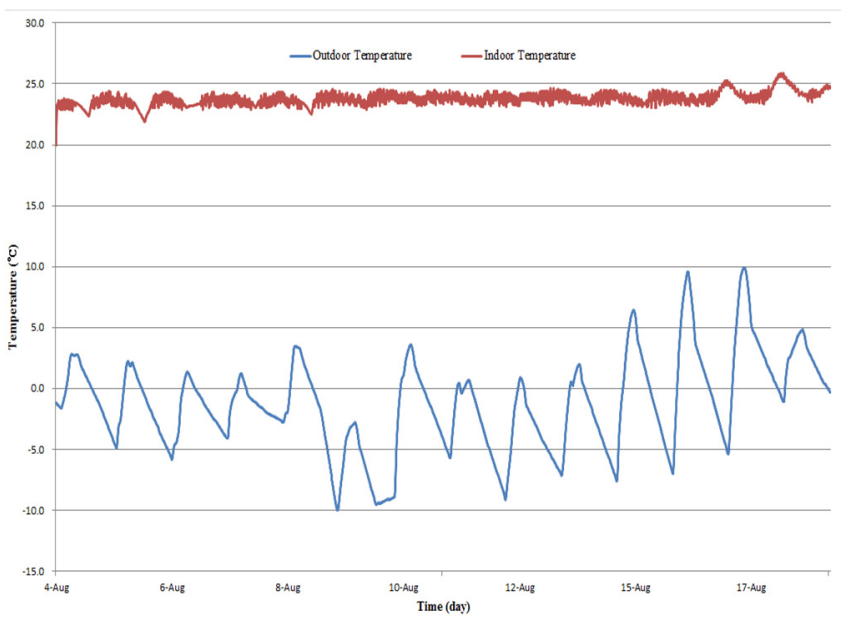

(b)

Figure 14. Indoor environment conditions of the Multi-GHP system in the winter: (a) existing operation condition of Multi-GHP system (Case 1-1); (b) sequencing operation condition of Multi-GHP system (Case 1-2). 
Figure 15 shows a graph of the Multi-GHP system summer cold water inlet-outlet temperatures and coefficient of performance (COP) in each case. The maximum COP of Case 1-1 appeared to be 3.25. The Multi-GHP system outlet temperature was approximately $7{ }^{\circ} \mathrm{C}$, and the inlet temperature was approximately $10{ }^{\circ} \mathrm{C}$. The wasted energy was consumed to meet the chilled water temperature of $7{ }^{\circ} \mathrm{C}$. In Case 1-2, which reflects the room load directly, the COP had a maximum of 4.2. The Multi-GHP system outlet water temperature was $12-18{ }^{\circ} \mathrm{C}$. Case 1-1 to Case 1-2 showed better performance than the control method, which reflected the load directly, resulting in energy savings.

Figure 16 shows a graph of the Multi-GHP system winter hot inlet-outlet temperatures and COP in each case. The maximum COP of Case 1-1 appeared to be 3.59. The Multi-GHP system outlet temperature was approximately $41{ }^{\circ} \mathrm{C}$, and the inlet temperature was approximately $45^{\circ} \mathrm{C}$. The wasted energy was consumed to meet the chilled water temperature of $41{ }^{\circ} \mathrm{C}$. In Case 1-2, which reflects the room load directly, the $C O P$ had a maximum of 4.15. The Multi-GHP system outlet water temperature was $40-43{ }^{\circ} \mathrm{C}$. Case 1-1 to Case 1-2 showed better performance than the control method, which reflected the load directly, resulting in energy savings.

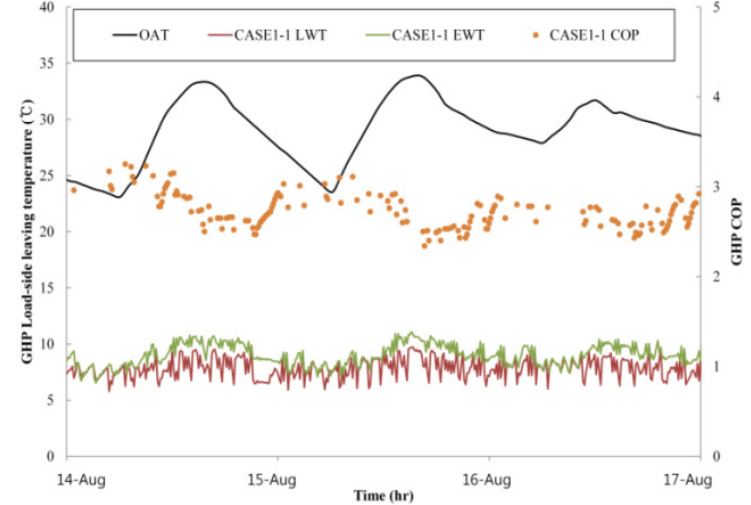

(a)

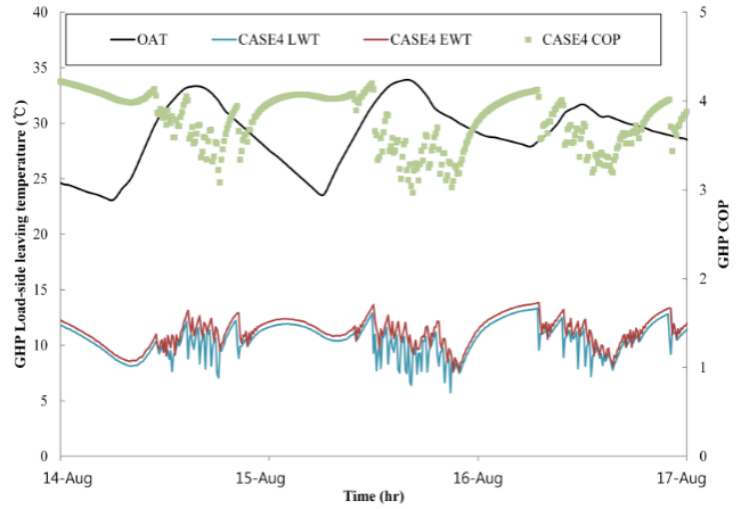

(b)

Figure 15. Coefficient of performance $(C O P)$ and summer cold water inlet-outlet temperatures for the Multi-GHP system: (a) existing operation condition of Multi-GHP system (Case 1-1); (b) sequencing operation condition of Multi-GHP system (Case 1-2).

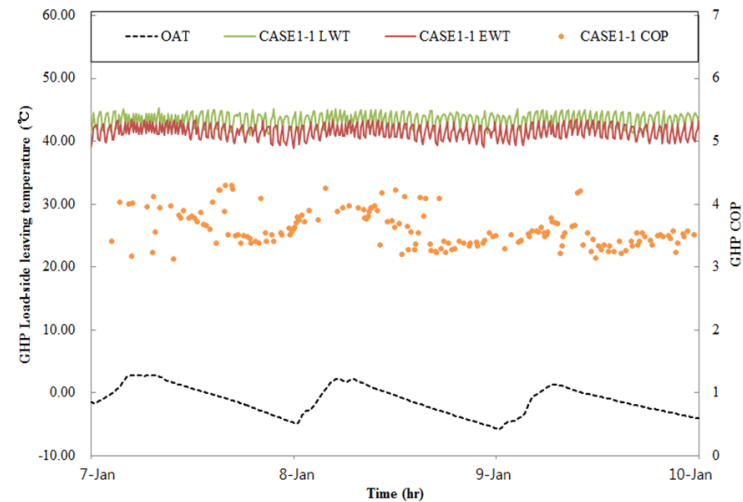

(a)

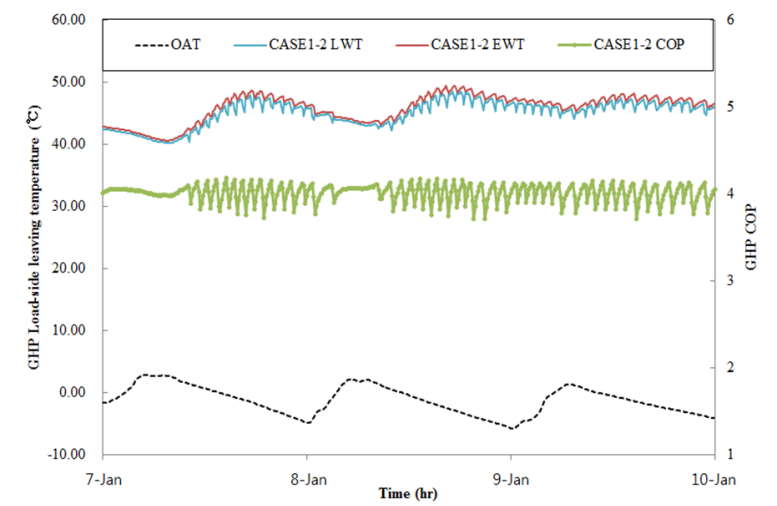

(b)

Figure 16. $C O P$ and winter hot water inlet-outlet temperatures for the Multi-GHP system: (a) existing operation condition of Multi-GHP system (Case 1-1); (b) sequencing operation condition of Multi-GHP system (Case 1-2). 
Figure 17 presents the results of comparative analysis of the Multi-GHP system energy consumption by each Case result. The total energy consumption of the existing operations was 469 GJ. In Case 1-2, which is the sequencing control according to room temperature, the total energy consumption was 208 GJ. The energy consumption of Case 1-2 was reduced by approximately $44 \%$ compared to the existing method. Case 1-2 showed the highest possible energy savings compared to most existing methods because it directly reflects the operation plan of the room load. A control method for Case 1-2, which can increase the efficiency of the Multi-GHP system, uses hybrid operations, and the total system can save the energy of the Multi-GHP system. A possible complex operation would be an efficient Multi-GHP system load that improves and reduces the ABS chiller-heater load and improves the energy efficiency.

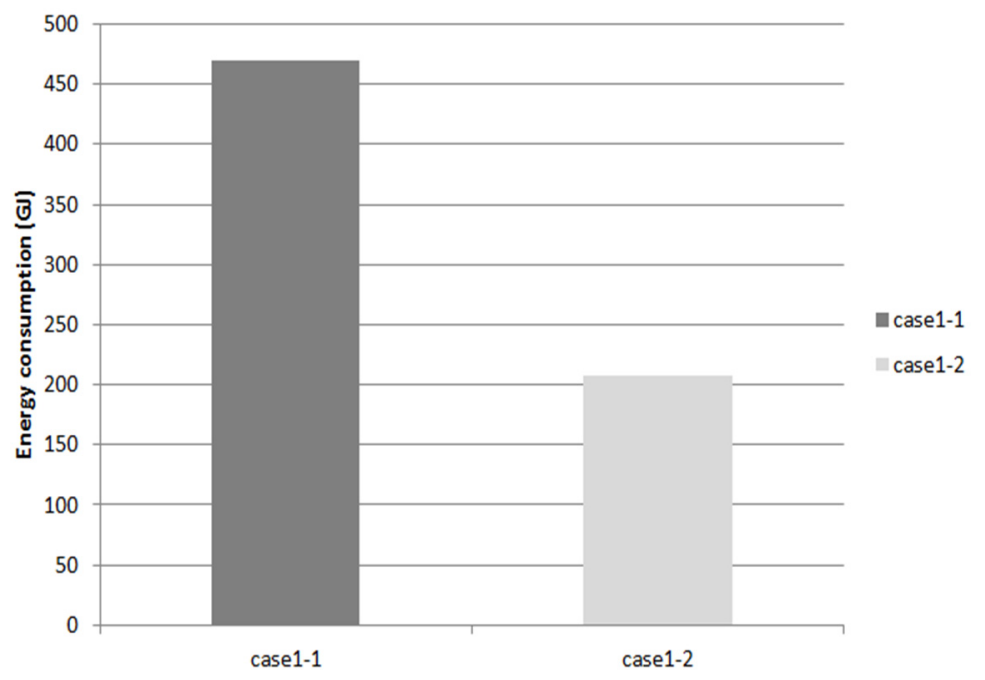

Figure 17. Comparison of the energy consumption for the Multi-GHP system: Case 1-1: existing operation condition of the Multi-GHP system; Case 1-2: sequencing operation condition of the Multi-GHP system.

4.2.2. Operation Cases of a Combination with the Multi-Geothermal Heat Pump (Multi-GHP) Systems and the Absorption (ABS) Chiller-heater System

Table 10 lists the simulation result of the Multi-GHP system for each Case. Figure 18 presents a performance and load relationship graph of the Multi-GHP system coefficient in each case. The maximum COP of Case 2-1 appears to be 3.4. The existing operations of the target building were a separate and independent Multi-GHP system and ABS chiller-heater. In this way, all heat source systems will be operated, even if the load of the building satisfies only efficient Multi-GHP system. As a result, energy wastage occurs. Therefore, the Case 2-2 system was combined with an existing heat source to enhance the efficiency of the Multi-GHP system, and achieve an efficient Multi-GHP system. In Case 2-2, which directly reflects the room load, the $C O P$ was a maximum of 4.2. Increasingly better performance in the Case 2-1 to Case 2-2 equipment was achieved using a control method that reflects the load directly.

Figure 19 compares the energy consumption of the heat source equipment of Cases 2-1 and 2-2. The Multi-GHP system energy use of Case 2 was reduced by $30 \%$ compared to Case 1 , and in the case of the ABS chiller-heater, the energy consumption was reduced by $80 \%$. In the existing method, although the outlet temperature of the Multi-GHP system was fitted by approximately $7^{\circ} \mathrm{C}$, the energy use of 
the Multi-GHP system was reduced. In addition, the improved efficiency by operating the Multi-GHP systems reduced by the use of the ABS chiller-heater. As a result, the total energy consumption of the heat source equipment was reduced by $78 \%$.

Table 10. Indoor environmental conditions for combination with the Multi-GHP systems and the ABS chiller-heater system.

\begin{tabular}{ccccc}
\hline Case 2 & Room air temperature $\left({ }^{\circ} \mathbf{C}\right)$ & $\mathbf{C O P}$ & HP energy consumption (GJ) & Total energy consumption (GJ) \\
\hline Case 2-1 & 23.5 & 3.35 & 469 & 7515.7 \\
Case 2-2 & 23.9 & 4.22 & 208 & 1431.98 \\
\hline
\end{tabular}

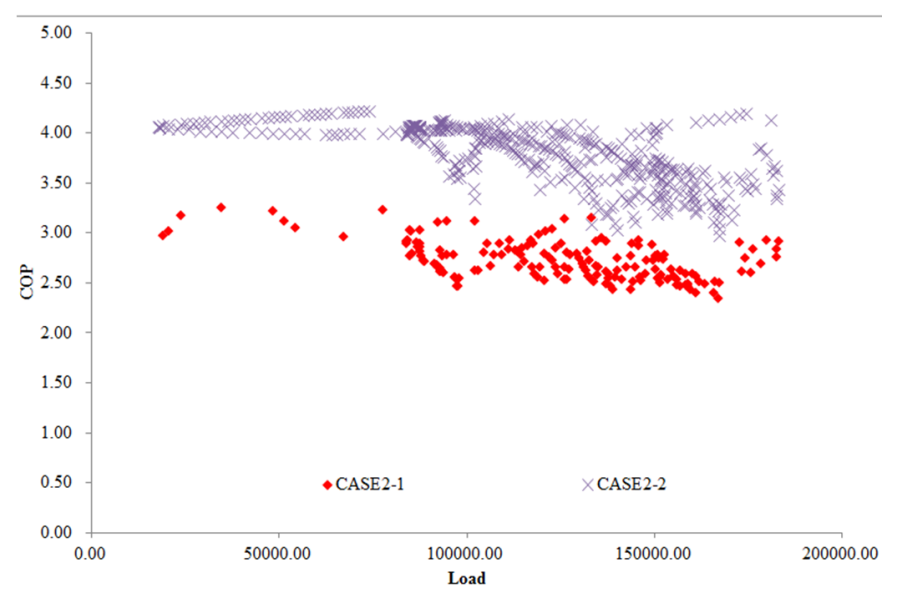

Figure 18. $C O P$ and load relationship graph of combination with the Multi-GHP systems and the ABS chiller-heater system: Case 2-1: existing operation condition of the Multi-GHP system and ABS chiller-heater system; Case 2-2: sequencing operation condition of the Multi-GHP system and ABS chiller-heater system.

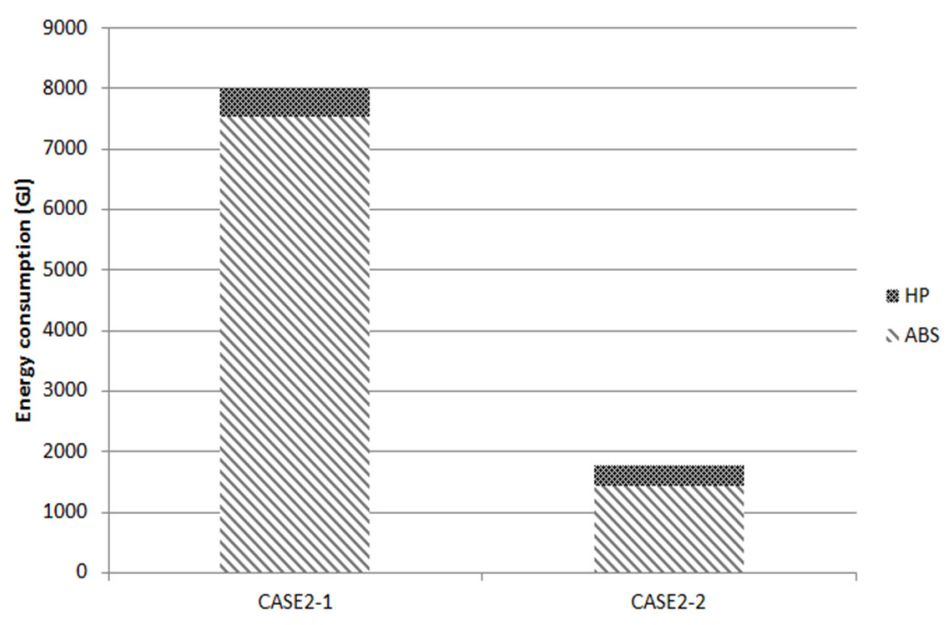

Figure 19. Comparison of the energy consumption for combination with the Multi-GHP systems and the ABS chiller-heater system.

\subsection{Future Research in Progress}

In most buildings, the Multi-GHP system is responsible for air conditioning the building part. In addition, the efficiency can decrease because the Multi-GHP system and the existing heat source are 
separate and operating independently. On the other hand, even if there is no load on the AHU served area, unnecessary energy is consumed to meet the chilled water set point temperature. This study developed as Multi-GHP system control algorithm according to the load condition, which is not in accordance with a set point. On the other hand, as a hospital building is being used, the developed algorithm has a problem in that it cannot be applied immediately. Therefore, a reliability validation and pre-simulation evaluation was conducted through short-term analysis. A simple comparison is difficult because the operating status of each building varies. Accordingly, future studies focusing on the integration of the Multi-GHP systems and ABS chiller-heater will compensate for the proposed algorithm. Complementary algorithms will be applied to building and long-term analysis will examine the effective use of the Multi-GHP system.

\section{Conclusions}

In this study, after selecting a building containing the actual installed GHP, the use of excellent GHP systems was maximized in terms of the energy efficiency. The methods of complex operation regarding ABS chiller-heater and GHP systems were proposed and evaluated through simulation:

(1) The Multi-GHP system of building operates to match the setting to the load side return temperature. Accordingly, on/off control was performed. On the other hand, no load area was used to fit the chilled water temperature at the set point. Therefore, unnecessary energy was consumed highlighting the need for a control plan.

(2) In the case that the return temperature of the Multi-GHP system is operated, energy wastage occurs regardless of the indoor load operation. Therefore, the actual load that reflects the room temperature monitoring control is proposed.

(3) Owing to the separation of the geothermal systems and heat source system, when the entire load is satisfied as a geothermal system, a waste of energy occurs in the operation. By incorporating the system, improved efficiency could be achieved by maximizing the Multi-GHP system operation; hence, the minimum use of the heat source plan is proposed. As a result, the Multi-GHP system energy use of hybrid operation condition of the Multi-GHP systems and the ABS chiller-heater system was reduced by $30 \%$ compared to the operation condition of the Multi-GHP system and the total energy consumption of the heat source equipment was reduced by $78 \%$. The results showed that the efficient operation of the Multi-GHP system is possible.

\section{Acknowledgments}

This study was supported by a grant (14CTAP-C078946-01) from Infrastructure and transportation technology promotion research Program funded by Ministry of Land, Infrastructure and Transport of Korean government.

\section{Author Contributions}

All authors contributed to this work. Young-Ju Jung performed the result analysis of simulation and wrote the major part of this article. Hyo-Jun Kim conducted the energy simulation. Kyung-Ju Shin Simulation data were summarized. Jae-Hun Jo proposed the case of the energy simulation and 
conducted data analysis. Yong-Shik Kim performed the result discussion and gave technical support. Young-Hum Cho was responsible for this article and gave conceptual advice.

\section{Conflicts of Interest}

The authors declare no conflict of interest.

\section{References}

1. Technical Report for Medium Term Oil Market; International Energy Agency (IEA): Paris, France, 2014.

2. Healy, P.F.; Ugursal, V.I. Performance and economic feasibility of ground-source heat pumps in cold climate. Int. J. Energy Res. 1997, 21, 857-870.

3. Lienau, P.J. Geothermal heat pump performance and utility programs in the United States. Energy Sources 1997, 19, 1-8.

4. Phetteplace, G.; Sullivan, W. Performance of a hybrid ground-coupled heat pump system. ASHRAE Trans. 1998, 104, 763-770.

5. Hepbasli, A. Performance evaluation of a vertical ground source heat pump system in Izmir, Turkey. Int. J. Energy Res. 2002, 26, 1121-1139.

6. Haehnlein, S.; Bayer, P.; Blum, P. International legal status of the use of shallow geothermal energy. Renew. Sustain. Energy Rev. 2010, 14, 2611-2625.

7. Luo, J.; Rohn, J.; Bayer, M.; Priess, A. Thermal efficiency comparison of borehole heat exchangers with different drillhole diameters. Energies 2013, 6, 4187-4206.

8. Rees, S.; Curtis, R. National deployment of domestic geothermal heat pump technology: Observations on the UK experience 1995-2013. Energies 2014, 7, 5460-5499.

9. Byun, J.K.; Jeong, D.H.; Choi, Y.D.; Shin, J.K. Analysis of fuel cell driven ground source heat pump systems in community buildings. Energies 2013, 6, 2428-2445.

10. Zhai, X.Q.; Wang, X.L.; Pei, H.T.; Yang, Y.; Wang, R.Z. Experimental investigation and optimization of a ground source heat pump system under different indoor set temperatures. Appl. Therm. Eng. 2012, 48, 105-116.

11. Bakirci, K.; Ozyurt, O.; Comakli, K.; Comakli, O. Energy analysis of a solar-ground source heat pump system with vertical closed-loop for heating applications. Energy 2011, 36, 3224-3232.

12. Yang, W. Experimental performance analysis of a direct-expansion ground source heat pump in Xiangtan, China. Energy 2013, 59, 334-339.

13. Kim, W.; Choi, J.; Cho, H. Performance analysis of hybrid solar-geothermal $\mathrm{CO}_{2}$ heat pump system for residential heating. Renew. Energy 2013, 50, 596-604.

14. Ozgener, O.; Hepbasli, A. Modeling and performance evaluation of ground source (geothermal) heat pump systems. Energy Build. 2007, 39, 66-75.

15. Salvalai, G. Implementation and validation of simplified heat pump model in IDA-ICE energy simulation environment. Energy Build. 2012, 49, 132-141.

16. Esen, H.; Inalli, M.; Esen, M. Technoeconomic appraisal of a ground source heat pump system for a heating season in eastern Turkey. Energy Convers. Manag. 2006, 47, 1281-1297. 
17. Ally, M.R.; Munk, J.D.; Baxter, V.D.; Gehl, A.C. Exergy analysis and operational efficiency of a horizontal ground-source heat pump system operated in a low-energy test house under simulated occupancy conditions. Int. J. Refrig. 2012, 35, 1092-1103.

18. Ally, M.R.; Munk, J.D.; Baxter, V.D.; Gehl, A.C. Exergy and energy analysis of a ground-source heat pump for domestic water heating under simulated occupancy conditions. Int. J. Refrig. 2013, $36,1417-1430$.

19. Chen, C.; Sun, F.; Feng, L.; Liu, M. Underground water-source loop heat-pump air-conditioning system applied in a residential building in Beijing. Appl. Energy 2005, 82, 331-344.

20. Sivasakthivel, T.; Murugaesan, K.; Sahoo, P.K. A study on energy and $\mathrm{CO}_{2}$ saving potential of ground source heat pump system in India. Renew. Sustain. Energy Rev. 2014, 32, 278-293.

21. Kong, D.S.; Jang, Y.S.; Ahn, B.H.; Huh, J.H. A Study on the Methodology of Design Optimization in Cooling System; Technical Report for the Society of Air-conditioning and Refrigerating Engineers of Korea, 2012.

22. Hwang, I.J.; Woo, N.S.; Lee, H.C. A study on the performance evaluation of hybrid energy system with geothermal and solar heat sources. Korean J. Air-Cond. Refrig. Eng. 2006, 18, 279-286.

23. Ozgener, O.; Hepbasli, A. Experimental investigation of the performance of a solar-assisted ground-source heat pump system for greenhouse heating. Int. J. Energy Res. 2004, 29, 217-231.

24. Ozgener, O.; Hepbasli, A. Experimental performance analysis of a solar assisted ground-source heat pump greenhouse heating system. Energy Build. 2005, 37, 101-110.

25. Nam, Y.J. Study on the optimum design of a heat pump system using solar and ground heat. Korean J. Air-Cond. Refrig. Eng. 2012, 24, 509-514.

26. Shu, N.; Kameda, N.; Kishida, Y.; Sonoda, H. Experimental and theoretical study on the optimal tilt angle of photovoltaic panels. J. Asian Archit. Build. Eng. 2006, 5, 399-405.

27. Jeon, J.U.; Park, J.S.; Myung, W.H.; Kim, Y.K.; Kim, Y.C. Analytical study on the optimal operating control of a hybrid geothermal plant. Korea Soc. Geotherm. Energy Eng. 2010, 6, 1-7.

28. Yu, S.W.; Jung, Y.J.; Kim, S.H.; Jo, J.H.; Kim, Y.S.; Cho, Y.H. A study on the optimized control strategies of geothermal heat pump system and absorption chiller-heater. Int. J. Energy Res. 2014, 38, 1083-1098.

29. Kalz, D.E.; Herkel, S.; Wagner, A. The impact of auxiliary energy on the efficiency of the heating and cooling system: Monitoring of low-energy buildings. Energy Build. 2009, 41, 1019-1030.

30. Kalz, D.E.; Pfafferott, J.; Herkel, S. Building signatures: A holistic approach to the evaluation of heating and cooling concepts. Build. Environ. 2010, 45, 632-646.

31. TRNSYS 17 Reference Manual; University of Wicons in Madison: Madison, WI, USA, 2010.

32. Haberl, J.S.; Claridge, D.E.; Culp, C. ASHRA's GUIDELINE 14-2002 for Measurement of energy and demand savings: How to determine what was really saved by the retrofit. In Proceedings of the International Conference for Enhanced Building Operations, College Station, TX, USA, 2005.

(C) 2015 by the authors; licensee MDPI, Basel, Switzerland. This article is an open access article distributed under the terms and conditions of the Creative Commons Attribution license (http://creativecommons.org/licenses/by/4.0/). 